\title{
Botany
}

American Journal of Botany 98(4): 638-653. 2011.

\section{A molecular PHylogenetic apProach to WeStern NORTH America endemic Artemisia ANd allies (Asteraceae): UNTANGLING THE SAGEBRUSHES ${ }^{1}$}

\author{
Sònia Garcia ${ }^{2,6}$, E. Durant McArthur ${ }^{3}$, Jaume Pellicer ${ }^{4}$, Stewart C. Sanderson $^{3}$, \\ JoAn VAllès ${ }^{5}$, AND Teresa GarnatJe ${ }^{2}$
}

\begin{abstract}
${ }^{2}$ Institut Botànic de Barcelona (IBB-CSIC-ICUB). Passeig del Migdia s/n 08038 Barcelona, Catalonia, Spain; ${ }^{3}$ Shrub Sciences Laboratory, Rocky Mountain Research Station, Forest Service, United States Department of Agriculture, Provo, Utah 84606 USA; ${ }^{4}$ Jodrell Laboratory, Royal Botanic Gardens, Kew, Richmond, Surrey TW9 3AB, United Kingdom; and ${ }^{5}$ Laboratori de Botànica, Facultat de Farmàcia, Universitat de Barcelona. Av. Joan XXIII s/n 08028 Barcelona, Catalonia, Spain
\end{abstract}

- Premise of the study: Artemisia subgenus Tridentatae plants characterize the North American Intermountain West. These are landscape-dominant constituents of important ecological communities and habitats for endemic wildlife. Together with allied species and genera (Picrothamnus and Sphaeromeria), they make up an intricate series of taxa whose limits are uncertain, likely the result of reticulate evolution. The objectives of this study were to resolve relations among Tridentatae species and their near relatives by delimiting the phylogenetic positions of subgenus Tridentatae species with particular reference to its New World geographic placement and to provide explanations for the relations of allied species and genera with the subgenus with an assessment of their current taxonomic placement.

- Methods: Bayesian inference and maximum parsimony analysis were based on 168 newly generated sequences (including the nuclear ITS and ETS and the plastid $\operatorname{trn} S^{\mathrm{UGA}}-\operatorname{trnf} M^{\mathrm{CAU}}$ and $\operatorname{trn} S^{\mathrm{GCU}}-\operatorname{trn} C^{\mathrm{GCA}}$ ) and 338 previously published sequences (ITS and ETS). Genome size by flow cytometry of species from Sphaeromeria was also determined.

- Key results: The results support an expanded concept and reconfiguration of Tridentatae to accommodate additional endemic North American Artemisia species. The monotypic Picrothamnus and all Sphaeromeria species appear nested within subgenus Tridentatae clade.

- Conclusions: A redefinition of subgenus Tridentatae to include other western North American endemics is supported. We propose a new circumscription of the subgenus and divide it into three sections: Tridentatae, Filifoliae, and Nebulosae. The position of the circumboreal and other North American species suggests that subgenus Artemisia is the ancestral stock for the New World endemics, including those native to South America.

Key words: Compositae; genome size; hybridization; polyploidy; reticulate evolution; sagebrush; Sphaeromeria; Tridentatae.

The genus Artemisia L. is the largest of tribe Anthemideae Cass. (Asteraceae Martinov), comprising around 500 species (Vallès and McArthur, 2001; Vallès and Garnatje, 2005), many of them ecologically and economically relevant. Some of them are important medicinal plants such as Artemisia аппиа L.,

\footnotetext{
1 Manuscript received 29 September 2010; revision accepted 20 December 2010.

The authors thank Dr. O. Hidalgo (Ohio University), I. Sánchez-Jiménez and L. Barres (Institut Botànic de Barcelona), and D. Vitales (Universitat de Barcelona) for helpful comments and support in phylogenetic analyses. Dr. L. M. Shultz (Utah State University) is acknowledged for providing leaf material of several accessions as well as for careful revision of the manuscript. Dr. M. P. Simmons and an anonymous reviewer are also thanked for their comments, corrections, and suggestions that improved the overall quality of the manuscript. Professor W. Greuter (Botanical Garden and Botanical Museum, Berlin) is thanked for his advice on taxonomical questions, and C. L. Christie is acknowledged for the pictures of Fig. 1. This work was subsidized by the projects CGL2007-64839-C02-01/BOS and CGL2007-64839-C02-02/BOS of the Spanish government and project 2009SGR00439 "Grup de Recerca Consolidat" from the Generalitat de Catalunya. S.G. was granted by the CSIC with a JAE-DOC contract and a short stay in the Shrub Sciences Laboratory (USDA) in Utah.

${ }^{6}$ Author for correspondence (e-mail: soniagarcia@ibb.csic.es)
}

doi:10.3732/ajb.1000386 whose component artemisinin is successfully used against malaria (Van der Meersch, 2005); others are used as condiments, as tarragon (A. dracunculus L.) or to make alcoholic beverages such as absinth (A. absinthium L.). Artemisia species are widely distributed in temperate areas in the northern Hemisphere (Bremer, 1994) but very sparsely in the southern Hemisphere, with fewer than 10 species there. Four or five subgenera are generally accepted: Artemisia, Absinthium (Mill.) Less., Dracunculus Besser, Seriphidium (Besser) Poljakov, and Tridentatae (Rydberg) McArthur; some treatments combine subgenera Artemisia and Absinthium in a single subgenus, Artemisia (Shultz, 2009). The classic subgeneric delimitations have been subject to rearrangement in the light of recent molecular studies, which in some cases do not support the traditional classifications and portray some of the classical subgenera as polyphyletic or paraphyletic (Watson et al., 2002; Vallès et al., 2003; Sanz et al., 2008; Tkach et al., 2008). Additionally, small segregate or monotypic genera are placed within Artemisia in these molecular phylogenies, at odds with traditional taxonomy. Processes like hybridization, introgression, and polyploidization, common in these plants, also complicate interpretation of relations at the molecular level (Ward, 1953; Estes, 1969; McArthur et al., 1981, 1988; Winward and McArthur, 1995; McArthur et al., 1998a; McArthur and Sanderson, 1999). 
The main speciation and diversification center of the genus Artemisia is Central Asia, and according to Tkach et al. (2008), 17 to 22 migrations may have occurred from Asia into North America and two to four from North America to Asia. The most representative group of North American endemic Artemisia is subgenus Tridentatae. The Tridentatae and allies characterize the landscape of western North America (sagebrush steppe) and are the most common shrubs in the western United States. They consist of 10 to 13 species (depending on the authority), all of them perennial, woody, and xerophytic, though as a group they occur over a broad habitat range because of their extraordinary variety of ecological specializations (West, 1983; Shultz, 2009). Sagebrushes form an intricate ecosystem crucial for the maintenance of its specific wildlife, including some endemic species such as the endangered sage grouse (genus Centrocercus Swainson) in which, under their cover, females incubate their eggs. The average life span of Artemisia tridentata Nutt., the most abundant Tridentatae species, ranges from 50 to $100 \mathrm{yr}$ (Winward, 1970), but some individuals live more than $200 \mathrm{yr}$ (Ferguson, 1964; McArthur and Stevens, 2004). The Intermountain West sagebrush steppe dates back to $12 \mathrm{Ma}$ (Davis and Ellis, 2010). In fact, North America, particularly the Intermountain West, can be considered an evolutionary hotspot for the genus, given the richness and success of these species there.

On the basis of a synapomorphy (homogamous flower heads) together with its large size (ca. 130 species) and their endemicity to the Old World, the Asian species belonging to the subgenus Seriphidium have been suggested as probable ancestors of the Tridentatae, with migration to North America across Beringia (Beetle, 1960; Ling, 1991, 1995a, b). In counterpoint, McArthur and Plummer (1978) and McArthur et al. (1981), while agreeing with this migration route, proposed that the herbaceous members of the subgenus Artemisia could have been differentiated in North America during the Pleistocene in response to climatic changes, giving origin to the species of the subgenus Tridentatae and other endemics. Jeffrey (1995) and Shultz (2009) supported the origin of the Tridentatae from subgenus Artemisia species on a phytochemical basis.

Pursh (1814) described the first species now included in the Tridentatae (= sagebrush), Artemisia cana Pursh (Pursh, 1814; Torrey and Gray, 1843; Rydberg, 1916). Subsequently, sagebrush classification over and under the subgeneric level has been difficult and subject to periodic rearrangement (Table 1). Initially, Tridentatae was placed in subgenus Seriphidium (Rydberg, 1916). McArthur raised the Tridentatae to subgeneric status (McArthur et al., 1981) and posited that the similarity with Seriphidium was a result of convergent evolution. The treatment of Seriphidium and Tridentatae as two independent clades draws support from several phylogenetic surveys of the genus (Watson et al., 2002; Vallès et al., 2003; Sanz et al., 2008; Tkach et al., 2008). Seriphidium has occasionally been segregated as an independent genus (Bremer and Humphries, 1993; Ling, 1991, 1995a, b), including Tridentatae species, and more recently in taxonomic and molecular phylogenetic treatments of the subtribe Artemisiinae (Watson et al., 2002; Ling et al., 2006). However, the separation of Seriphidium from the genus Artemisia is not supported by cpDNA restriction sites or internal transcribed spacer (ITS) and external transcribed spacer (ETS) sequence phylogenies (Kornkven et al., 1998, 1999; Torrell et al., 1999; Sanz et al., 2008), nor on a morphological basis. Also, the Tridentatae occasionally have been treated at the generic level (Weber, 1984; and L. M. Shultz, Utah State University, Logan, Utah, USA, personal communication), but as for Seriphidium, the generic rank is considered unsuitable (Oberprieler et al., 2007; Funk et al., 2009).

The interspecific relations and boundaries of the Tridentatae and allies are complex and unresolved. It sometimes has been considered as a monophyletic group (Kornkven et al., 1998, 1999; Vallès et al., 2003), but the possibility of independent introductions of Artemisia from the Old World to the New World complicates New World Artemisia evolutionary history (Tkach et al., 2008). Two Tridentatae lineages have been proposed on the basis of some morphological and ecological characteristics (Ward, 1953; Beetle, 1960; Shultz, 1983; see Table 1), but the available molecular data do not support recognition of these lineages (Kornkven et al., 1998, 1999; Watson et al., 2002; Riggins, 2008). Moreover, several species have been included and subsequently excluded in numerous studies based on different approaches such as morphological, cytogenetical, and chemical (Rydberg, 1916; Hall and Clements, 1923; Ward, 1953; Beetle, 1960; Holbo and Mozingo, 1965; Kornkven et al., 1998, 1999). Placement of species like Artemisia bigelovii A. Gray, A. californica Less., A. filifolia Torr., A. palmeri A. Gray, A. pygmaea A. Gray, and A. rigida (Nutt.) A. Gray is particularly problematic. Shultz (2009), in her recent monograph of the Tridentatae, advocates an extended concept of the subgenus, recognizing two sections: Tridentatae L. M. Shultz and Nebulosae L. M. Shultz, the latter created to accommodate some other North American endemic Artemisia on the basis of molecular studies (Watson et al., 2002). Molecular cytogenetics and genome size data (Garcia et al., 2007, 2008, 2009) also have shed light in particular cases and support a more restrictive concept of the Tridentatae, the "Tridentatae core" or true sagebrushes, which may be partly equivalent to section Tridentatae sensu Shultz (2009). Moreover, two North American endemic genera, the monotypic Picrothamnus Nutt. and Sphaeromeria Nutt. (nine species, with eight of them being worthy of rare and endangered species classification; Holmgren et al., 1976), also have appeared embedded in an endemic North American Artemisia clade in some recent studies (Watson et al., 2002; Vallès et al., 2003; Riggins, 2008; Sanz et al., 2008). Apart from many similar morphological and ecological features, these species share the presence of interxylary cork, typical of Tridentatae species (Holmgren et al., 1976).

Given the complexity that most researchers have faced when working in this group, our attempt to resolve its phylogenetic relations includes four molecular data sets. As nuclear gene regions, the rDNA ITS and ETS were chosen for study and analysis. The ITS region had been tested previously in the Tridentatae (Kornkven et al., 1998; Garcia et al., 2008), but we included this region again in this study, as all subspecific entities of the Tridentatae, most of the remaining North American endemic Artemisia, and two closely related genera (Picrothamnus and Sphaeromeria) are included for the first time in a unique data set. The virtues of this region (biparentally inherited, high rates of base substitution, ease of amplification with universal primers) have led to extensive ITS use by molecular systematists (Baldwin et al., 1995), though either complete or incomplete concerted evolution and lineage sorting, among other things, can be a source of problems in phylogenetic reconstructions (Mayol and Rosselló, 2001; Álvarez and Wendel, 2003; Nieto Feliner and Rosselló, 2007). Because for some recently evolved angiosperm lineages the ITS is not sufficiently informative as a result of insufficient sequence variation, we included data from a neighboring rDNA region, the ETS. It is generally longer than ITS, easily amplifiable with universal primers, and has proved 


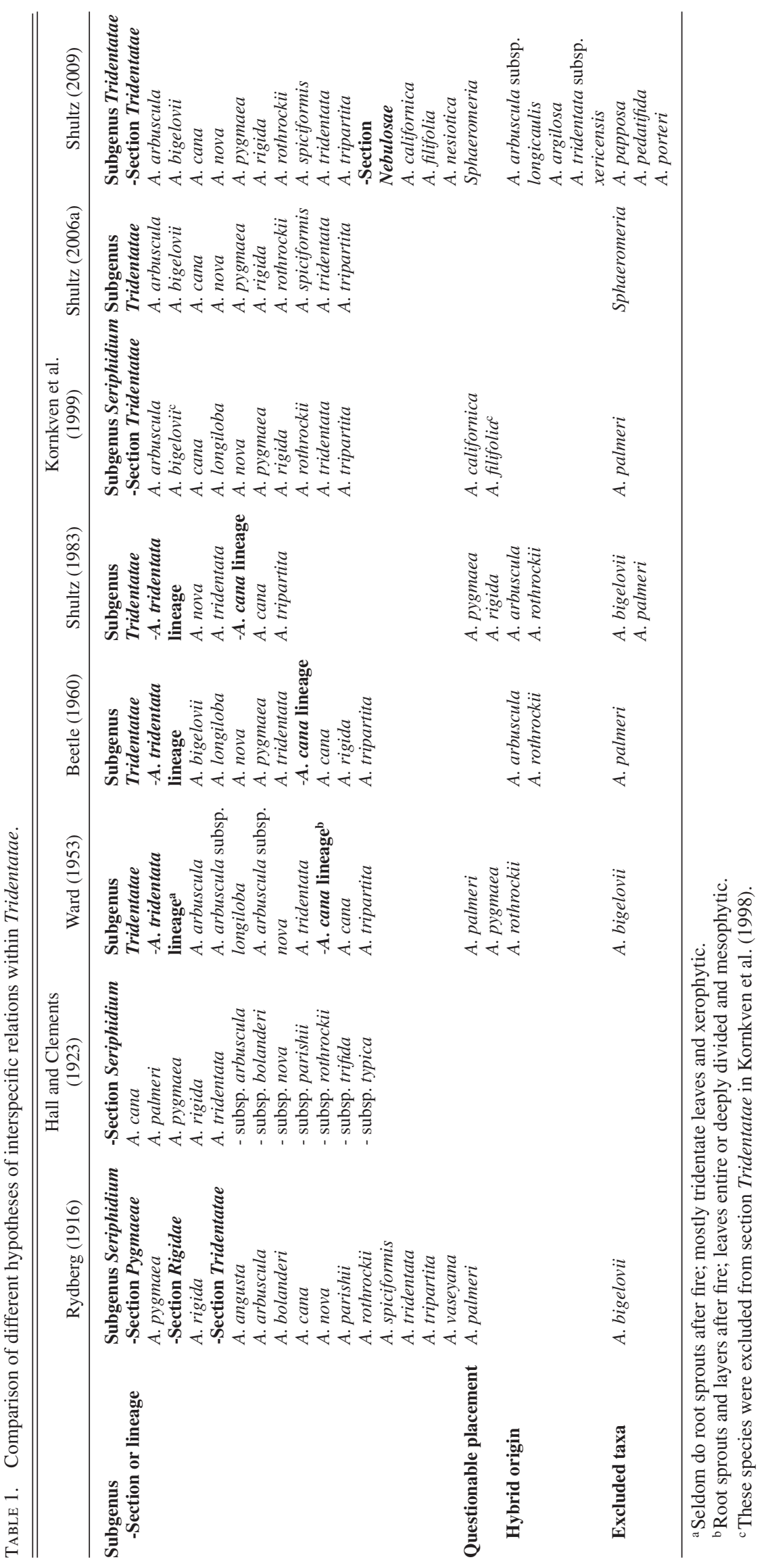


useful at low taxonomic levels (Linder et al., 2000), including in recent studies in Artemisia (Sanz et al., 2008; Tkach et al., 2008; Pellicer et al., 2010a), though, as with the ITS region, it is not free from problems related to concerted evolution.

Since a combination of different genomes is considered one of the best tools for phylogenetic reconstructions (Qiu et al., 1999), we decided to add chloroplast sequence data to our molecular study. On the basis of the pioneering work of Shaw et al. (2005), we selected $\operatorname{trn} S^{\mathrm{UGA}}-\operatorname{trnf} M^{\mathrm{CAU}}$ and $\operatorname{trn} S^{\mathrm{GCU}}-\operatorname{trn} C^{\mathrm{GCA}}$, the latter exclusive to the Asteraceae because of two inversions in the LSC region of the chloroplast DNA (Kim et al., 2005). These two fragments occur between the regions considered to provide the greatest number of potentially informative characters across all phylogenetic lineages (Shaw et al., 2005).

In summary, the current study attempts to resolve phylogenetic relations for these taxa, with these specific goals: (1) to assess the circumscription, boundaries, and internal relations of members of subgenus Tridentatae in the genus Artemisia and to hypothesize their likely ancestral stock; (2) to explain the relation with genera Sphaeromeria and Picrothamnus and to assess their generic independence and evaluate their present taxonomy; and (3) to identify the (subgeneric) placement of the other North American endemic Artemisia and of some other taxa of likely hybrid origin. Finally, the paper aims to contribute and analyze genome size data for the first time for genus Sphaeromeria, complementing the representation of the North American endemic Artemisiinae (Garcia et al., 2008).

\section{MATERIALS AND METHODS}

Taxon sampling and data sets used-First data set (sagebrushes)—Plant material for 42 populations was obtained (Table 2), including all subgenus Tridentatae species, subspecies (22 taxa), and some taxa of likely hybrid origin ( $A$. argilosa Beetle, A. arbuscula Nutt. subsp. longicaulis Winward et McArthur, and A. tridentata Nutt. subsp. xericensis Winward ex R. Rosentreter et R. G. Kelsey following Shultz [2009]), as well as many North American endemic Artemisia that had been considered related to or included in the Tridentatae in previous research efforts (seven taxa), eight Sphaeromeria (unfortunately, we were not able to extract DNA from Sphaeromeria martirensis [Wiggins] A. H. Holmgren, L. M. Shultz et Lowrey, which would have completed the representation of the genus), and one population of Picrothamnus desertorum Nutt. Because previous phylogenetic approaches to the genus Artemisia (Torrell et al., 1999; Vallès et al., 2003; Sanz et al., 2008; Tkach et al., 2008) showed unclear sister-group relations for the Tridentatae, we followed the criteria of adding complementary species representing each subgenus of Artemisia and not being endemic to North America (four taxa). Phylogenetic analyses have been performed with and without subspecies/hybrids, but since clades did not change significantly, we kept results of the complete set of taxa. All nuclear and chloroplast DNA sequences (168) were newly generated. Table 2 shows the provenance of all the species investigated and the GenBank accession numbers for DNA sequences. All cited taxa were sampled for DNA sequencing, and, in addition, the eight Sphaeromeria species also were sampled for nuclear DNA content assessment.

Second data set (global)—To establish the placement of subgenus Tridentatae within the genus Artemisia and determine the more closely related groups, our first data set (excluding subspecies and putative hybrid taxa) was supplemented with ITS and ETS sequences of the Artemisia and allies, available at GenBank (110 species, 220 sequences). Sequences belong to previous molecular systematic approaches to Artemisia (Torrell et al., 1999; Vallès et al., 2003; Sanz et al., 2008; Tkach et al., 2008; Pellicer et al., 2010b), and GenBank accession numbers can be consulted in Appendix S1 (see Supplemental Data with the online version of this article).

Molecular techniques-DNA extraction, amplification, and sequencingWe extracted total genomic DNA using either the CTAB method of Doyle and
Doyle (1987) as modified by Soltis et al. (1991) or the Nucleospin Plant (Macherey-Nagel, GmbH et Co., Düren, Germany), depending on the quality of the vegetal material, either from silica gel-dried leaves collected in the field, fresh leaves of plants cultivated in greenhouses (Institut Botànic de Barcelona, CSIC; Facultat de Farmàcia, Universitat de Barcelona), or herbarium material (see Table 2). Polymerase chain reaction (PCR) was performed by using either GRI Labcare (Essex, UK) or MJ Research Inc. (Watertown, Massachusetts, USA) thermal cyclers in a $25-\mu \mathrm{L}$ volume. Subsequently, PCR products were purified with either the QIAquick PCR purification kit (Qiagen, Valencia, California, USA) or the DNA Clean and Concentrator-5 D4003 (Zymo Research, Orange, California, USA). Direct sequencing of the amplified DNA segment was performed with the Big Dye Terminator Cycle Sequencing v3.1 (PE Biosystems, Foster City, California, USA). Nucleotide sequencing was carried out at the Serveis Cientificotècnics (Universitat de Barcelona) on an ABI PRISM 3700 DNA analyzer (PE Biosystems, Foster City, California, USA).

ITS region-Double-stranded DNA of the ITS region (including ITS1, 5.8S gene, and ITS2) was amplified by PCR with either 1406F (Nickrent et al., 1994) or ITS1 (White et al., 1990) as forward primers and ITS4 (White et al., 1990) as the reverse primer. The PCR profile used for amplification was $94^{\circ} \mathrm{C} 2 \mathrm{~min}$; $30 \times\left(94^{\circ} \mathrm{C} 1 \mathrm{~min} 30 \mathrm{~s} ; 55^{\circ} \mathrm{C} 2 \mathrm{~min} ; 72^{\circ} \mathrm{C}, 3 \mathrm{~min}\right) ; 72^{\circ} \mathrm{C} 15 \mathrm{~min}$. Because the mean length of this region is relatively short ( $653 \mathrm{bp}$ ), only the ITS4 primer was used in sequencing in most cases, though both forward primers were used at times when necessary.

ETS region-Double-stranded DNA of the ETS region was amplified with the ETS1f as forward and the 18SETS as reverse primers (Baldwin and Markos, 1998 ) and occasionally also with the $18 \mathrm{~S} 2 \mathrm{~L}$ as reverse primer (Linder et al., 2000). The PCR profile used for amplification was $95^{\circ} \mathrm{C}, 5 \mathrm{~min} ; 30 \times\left(94^{\circ} \mathrm{C}, 45 \mathrm{~s}\right.$; $\left.50^{\circ} \mathrm{C}, 45 \mathrm{~s} ; 72^{\circ} \mathrm{C}, 40 \mathrm{~s}\right) ; 72^{\circ} \mathrm{C}, 7 \mathrm{~min}$. Because of the mean length of this region (1624 bp), both ETS1f and 18SETS were used as sequencing primers, and also the internal primers AST1F and AST1R (Markos and Baldwin, 2001) were used occasionally.

$\operatorname{trn} S^{\mathrm{UGA}}-\operatorname{trnf} M^{\mathrm{CAU}}$-This region was amplified with $\operatorname{trn} S^{\mathrm{UGA}}$ (forward) and trnfM $M^{\mathrm{CAU}}$ (reverse) primers (Demesure et al., 1995). The amplification parameters were $80^{\circ} \mathrm{C}, 5 \mathrm{~min} ; 30 \times\left(94^{\circ} \mathrm{C}, 30 \mathrm{~s} ; 62^{\circ} \mathrm{C} 1 \mathrm{~min} 30 \mathrm{~s} ; 72^{\circ} \mathrm{C} 2 \mathrm{~min}\right) 72^{\circ} \mathrm{C}$, 5 min. $\operatorname{trn} S^{\mathrm{UGA}}$ was used as the sequencing primer, but occasionally trnf $M^{\mathrm{CAU}}$ was also needed. The mean length of this region was $1077 \mathrm{bp}$.

trn $S^{\mathrm{GCU}}$-trn $C^{\mathrm{GCA}}$-The primers $t r n S^{\mathrm{GCU}}$ (Shaw et al., 2005), as forward, and trn $C^{\mathrm{GCA}} \mathrm{R}$ (modified by Shaw et al., 2005, from Ohsako and Ohnishi, 2000), as reverse, were used to amplify this region. The PCR parameters were the same as for $\operatorname{trn} S^{\mathrm{UGA}}-\operatorname{trnf} M^{\mathrm{CAU}}$. This fragment was sequenced with the primer $\operatorname{trn} C^{\mathrm{GCA}} \mathrm{R}$, though $\operatorname{trn} S^{\mathrm{UGA}}$ was occasionally needed. The mean length of this region was $841 \mathrm{bp}$.

DNA cloning - Although for most taxa, direct sequencing performed well, yielding clean and unambiguous sequences, in a very few cases (ETS of Artemisia deserti Krasch. and ETS and ITS of Sphaeromeria capitata Nutt.), DNA sequences were difficult or impossible to read. In these cases, we conducted cloning of PCR products with the TOPO TA Cloning kit from Invitrogen (Carlsbad, California, USA), following the manufacturer's instructions. There were no significant changes between clones in both cases (clades posterior probability $[\mathrm{PP}]=0.98-1.0, \mathrm{BS}=96-100 \%$ in preliminary analyses), so only one clone per species was selected for the final analyses.

Flow cytometry measurements-For genome size estimation, flow cytometry was used. Petunia hybrida Vilm. 'PxPc6' ( $2 \mathrm{C}=2.85 \mathrm{pg}$, Marie and Brown, 1993) was used as the internal standard. Fresh leaf tissue of the standard and the target species was chopped together in $600 \mu \mathrm{L}$ of Galbraith's isolation buffer (Galbraith et al., 1983) supplemented with $100 \mu \mathrm{g} / \mathrm{mL}$ ribonuclease A (RNase A, Boehringer, Meylan, France), stained with $36 \mu \mathrm{L}$ of $1 \mathrm{mg} / \mathrm{ml}$ propidium iodide (Sigma-Aldrich Química, Alcobendas, Spain) to a final concentration of $60 \mu \mathrm{g} / \mathrm{mL}$, and kept on ice for $20 \mathrm{~min}$. We sampled five individuals for each population, and two replicates of each individual were independently processed. The flow cytometer used was an Epics XL (Coulter Corporation, Hialeah, Florida, USA) at the Serveis Cientificotècnics (Universitat de Barcelona). More details about the method we followed are described in Garcia et al. (2008).

Data analyses - Construction and editing of sequence matrices-DNA sequences were edited with Chromas Lite 2.01 (Technelysium PTy, Tewantin, Queensland, Australia) and subsequently assembled with Bioedit Sequence Alignment Editor 7.0.9.0 (Hall, 1999), aligned with ClustalW Multiple Alignment v. 1.4 (Thompson et al., 1994), and corrected manually. The DNA data sets generated included the following: (1) the first data set (the sagebrushes) 


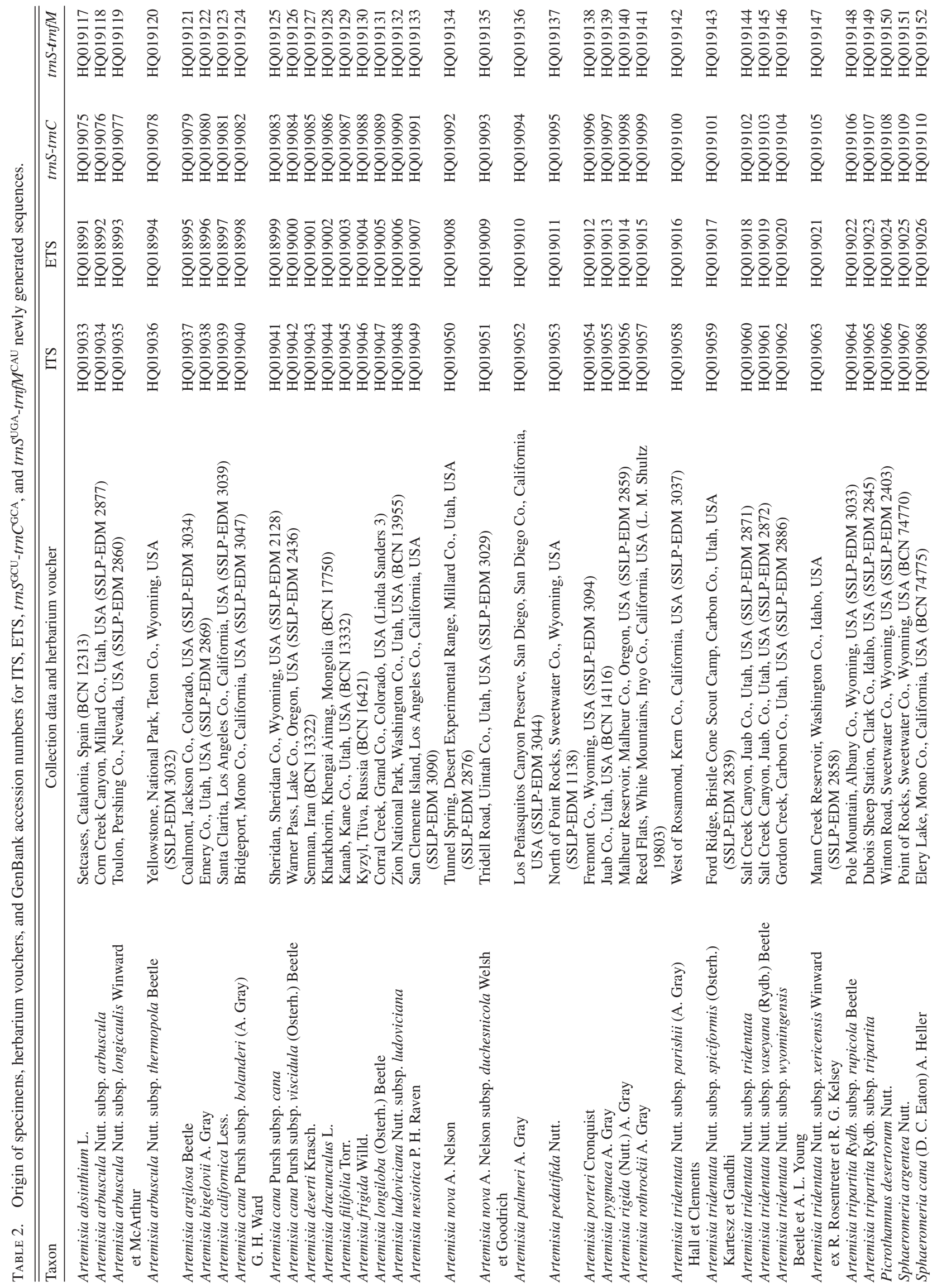


included the whole ITS (ITS1-5.8S-ITS2), the ETS (excepting some limited regions of ambiguous alignment in the middle of the region), and the complete chloroplast $\operatorname{trn} S^{\mathrm{UGA}}-\operatorname{trnf} M^{\mathrm{CAU}}$ and $\operatorname{trn} S^{\mathrm{GCU}}-\operatorname{trn} C^{\mathrm{GCA}}$ sequences; (2) the second data set (global) addressed to delimit Tridentatae and allies within the genus Artemisia as a whole included the ITS1, ITS2, and the 3' side of ETS. Independent and combined nuclear and plastid matrices were generated and analyzed, though results were kept only for the combined ITS+ETS sets ("sagebrushes" and global) and $\operatorname{trn} S^{\mathrm{UGA}}$-trnf $M^{\mathrm{CAU}}+\operatorname{trn} S^{\mathrm{GCU}}-\operatorname{trn} C^{\mathrm{GCA}}$ ("sagebrushes" only). The sequence matrices are available in Appendices S2 to S7 (see Supplemental Data with the online version of this article).

Phylogenetic analyses-For the first data set (the sagebrushes), the complementary species added to delimit the subgenus were A. absinthium, A. deserti, A. dracunculus, and A. frigida Willd. (following the criteria of [1] choosing a representation of each subgenus of Artemisia and [2] not being endemic to North America). For the second data set (global), complementary species were those used as outgroup taxa following previous phylogenetic analyses of the group (Sanz et al., 2008, and Tkach et al., 2008): Ajania fastigiata (C. Winkler) Poljakov, Brachanthemum titovii Krasch., Chrysanthemum maximowiczii V. Komarov, Ch. zawadskii Herbich, Elachanthemum intricatum (Franch.) Y. Ling et Y. R. Ling, Hippolytia megacephala (Rupr.) Poljakov, Lepidolopsis turkestanica (Regel et Schmalh.) Poljakov, Nipponanthemum nipponicum (Franchet ex Maxim) Kitam, Tanacetum parthenium (L.) Sch. Bip., and Turaniphytum eranthemum (Bunge) Poljakov. To increase the information contributed by plastid data, gaps in chloroplast DNA (21) were coded in a binary matrix (0: absence / 1: presence), following the simple indel coding method (Simmons and Ochoterena, 2000) that was added to the combined trnS$\operatorname{trnfM}$ and $\operatorname{trnS}$-trnC data set. Nuclear gaps were not coded, as according to our observations and previous experience (Sanz et al., 2008; Pellicer et al., 2010b), these data did not provide significant information.

Model selection and Bayesian inference analysis-Evolutionary models were selected with MrModeltest 2.3 (Nylander, 2004) under the Akaike Information Criterion (AIC; Akaike, 1974) and the hierarchical Likelihood Ratio Tests (hLRT) (Posada and Buckley, 2004). The chosen models were subsequently used to perform Bayesian MCMC analyses (Yang and Rannala, 1997) with MrBayes 3.1.2 (Huelsenbeck and Ronquist, 2001). Four Markov chains were run simultaneously for 1 to $6 \cdot 10^{6}$ generations (depending on the data set), and these were sampled every 100 generations. Data from the first 1000 to 6000 generations were discarded as the "burn-in" period, after confirming that likelihood values had stabilized before the 1000th to 6000th generation. Posterior probabilities (PP) were estimated through the construction of a $50 \%$ majority rule consensus tree. The output trees were edited with FigTree v. 1.2.2. (Edinburgh, UK) and Adobe Photoshop CS3 Extended v. 10.0.1 (Dublin, Ireland).

Parsimony analysis-These analyses involved heuristic searches conducted with PAUP* 4.0b10 (Swofford, 2003) under the maximum parsimony criterion. Uninformative characters were excluded from the analyses, and outgroups were defined. The standard parameters were as follows: MulTrees 100 random taxon additions, with Tree Bisection Reconnection (TBR) branch swapping, one tree held at each step and characters equally weighted. Posterior heuristic searches were developed with the constraint of saving no more than 1000 trees larger or equal to the tree lengths. To obtain estimates of support for branches of tree nodes, faststep bootstrap analyses (Felsenstein, 1985) as implemented in PAUP* were carried out with the use of 1000 replicates, 10 random sequence additions per replicate, and no branch swapping. This is an alternative for large data sets, providing similar estimates to those performed with branch swapping (Mort et al., 2000).

Split decomposition-Given that processes like hybridization, introgression, and polyploidy can be important factors in the evolution of species diversity (reticulate evolution), it is possible that a bifurcating tree may not explain the whole evolutionary history of a given group (Winkworth et al., 2005). Although mostly bifurcating trees are used here to explain and analyze relations among these species, we also have included a Neighbor-Net splits graph analysis (with uncorrected p-distances), as implemented in SplitsTree 4 (Huson and Bryant, 2006).

Statistical analyses-The nonparametric Mann-Whitney test was carried out to evaluate significance of genome size differences among groups, after testing for normality of the data set with negative result. Analyses were performed only on $1 \mathrm{Cx}$ values, corrected for the polyploids on the basis of results of Garcia et al. (2008), to avoid the influence of the genome downsizing effect that polyploids may suffer (Leitch and Bennett, 2004). In addition to data obtained in the current study, those from a previous paper on Artemisia genome size (Garcia et al., 2008) have been included in the analyses for comparative purposes. Statistical analyses were performed with STATA v.10 (StataCorp LP, College Station, Texas, USA). 


\section{RESULTS}

Phylogenetic analyses-The resulting phylogenetic analyses produced the trees shown in Fig. 1 (ITS+ETS reconstruction of the reduced data set), Fig. 2 (ITS1+ITS2+3'ETS reconstruction of the global data set), and Fig. S8 (trnStrnC+trnS-trnfM regions of the reduced data set; see Supplemental Data with the online version of this article). The splits graph analysis (corresponding to the same data set and regions of Fig. 1 but excluding subspecies and presumed hybrid taxa) is shown in Fig. 3.

Separated and combined data set analyses-We tested congruence among nuclear and chloroplast data sets with the incongruence length difference test (ILD) (Farris et al., 1994), implemented in PAUP* as the partition homogeneity test
(Swofford, 2003). The test did not find significant incongruence between the chloroplast regions $(P=0.23)$ but did report significant incongruence between the nuclear ones $(P<0.01)$ in all data sets. However, as none of the apparent topological conflict was between well-supported clades in the different analyses performed, nuclear regions were nevertheless combined (see trees in Figs. 1 and 2) after analyzing the nuclear regions separately, as in previous studies (Acevedo-Rosas et al., 2004; Hoggard et al., 2004; Li et al., 2007; Hidalgo et al., 2008; Englund et al., 2009). Although these nuclear regions form part of the same transcriptional unit, ETS apparently evolves faster than ITS (Baldwin and Markos, 1998; Bena et al., 1998), which could explain some of the incongruence, considering that the ILD test does not distinguish whether incongruence comes from different phylogenetic histories or from different rates of evolution (Li et al., 2007). Differential unequal concerted evolution
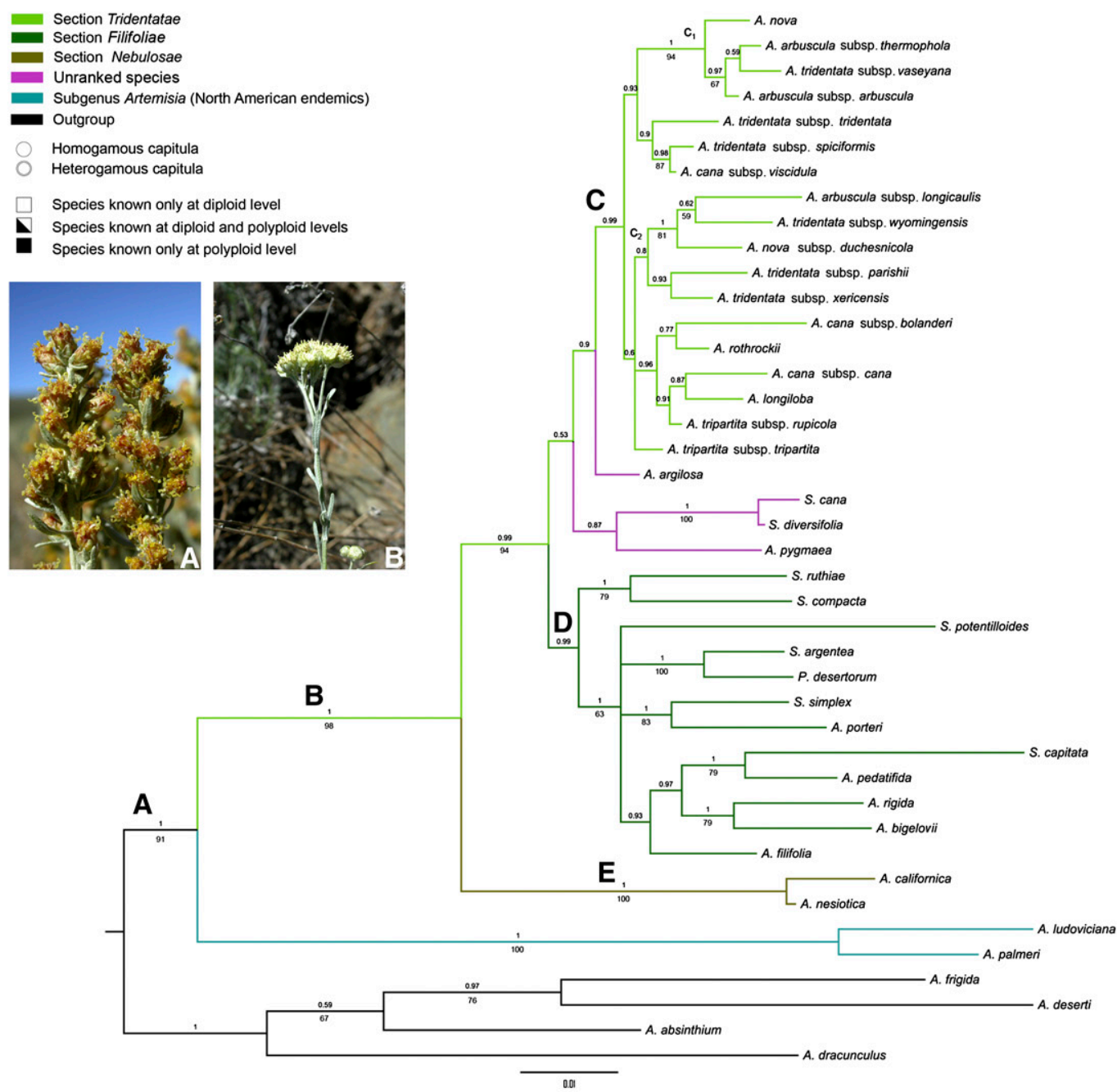

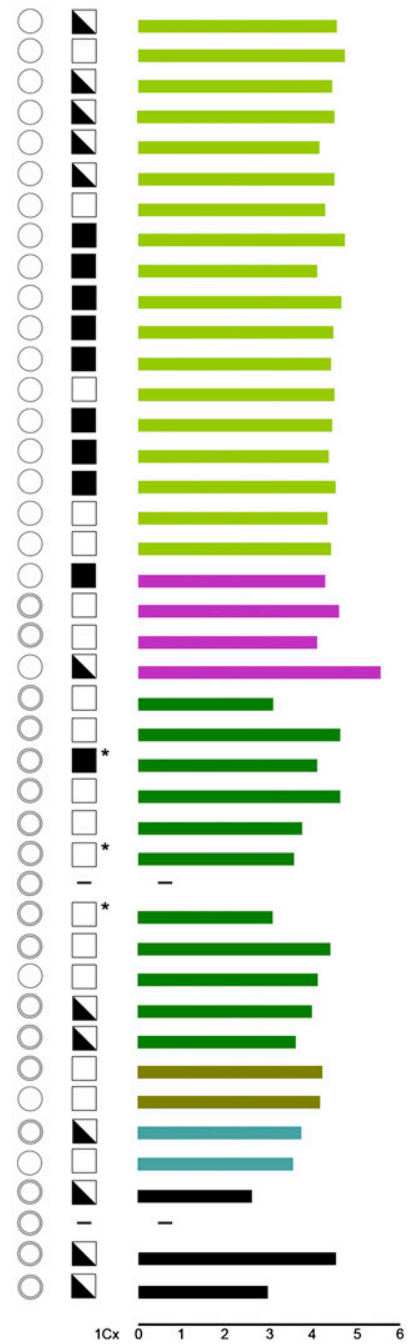

Fig. 1. Phylogenetic reconstruction (midpoint phylogram) obtained through combined analysis of ITS and ETS sequence data for 42 taxa (reduced set, "sagebrushes"). Majority rule consensus tree (50\%) based on Bayesian MCMC inference with Bayesian clade-credibility values (posterior probability $>0.5$ ) above branches and parsimony bootstrap percentages (>50\%) below branches. Flower heads composition and ploidy levels known for each species are depicted and monoploid genome sizes (1Cx) represented as bar graphs: note homogeneous genome size data for species from section Tridentatae and heterogeneous values for section Filifoliae. Asterisk (*) indicates ploidy levels inferred from known DNA amounts. Clades discussed in the text are indicated by letters. Scale bar indicates number of substitutions per site. Different inflorescence types are shown in the photographs: (A) Racemiform synflorescence of Artemisia tridentata subsp. vaseyana; (B) corymbiform synflorescence of Sphaeromeria cana. Both specimens are from White Mountains, Inyo Co., California (2003 Christopher L. Christie; photos reproduced with permission). 


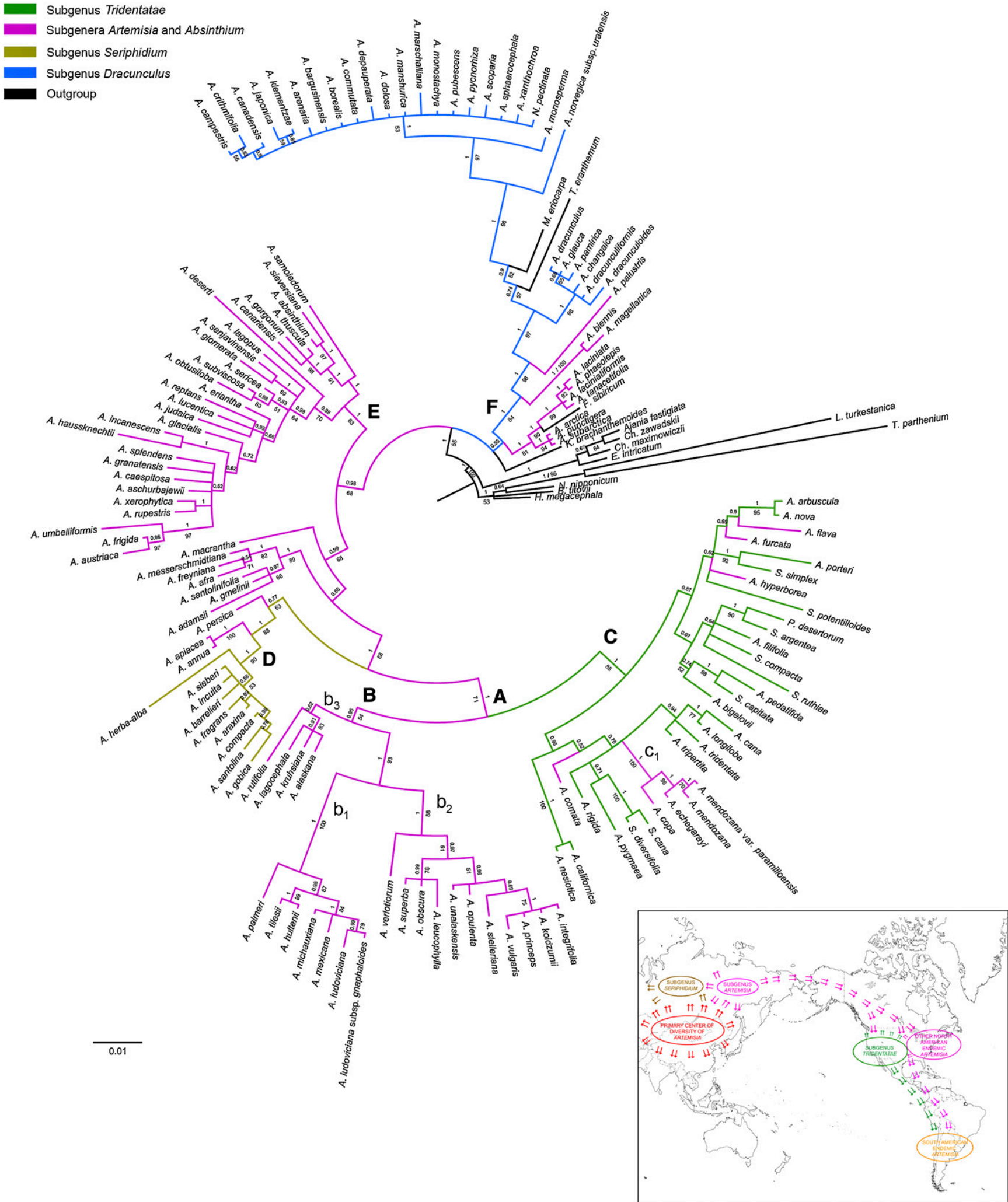

Fig. 2. Phylogenetic reconstruction (midpoint phylogram) obtained through combined analysis of ITS1, ITS2, and 3' ETS sequence data for 152 taxa (global set, genus Artemisia). Majority rule consensus tree (50\%) based on Bayesian inference with Bayesian clade-credibility values (posterior probability $>0.5)$ above branches and parsimony bootstrap percentages $(>50 \%)$ below branches. Clades discussed in the text are indicated by letters. Bar indicates number of substitutions per site. The map shows our hypothesis on the colonization of genus Artemisia through the Bering Strait to North America and its subsequent diversification in the New World. 


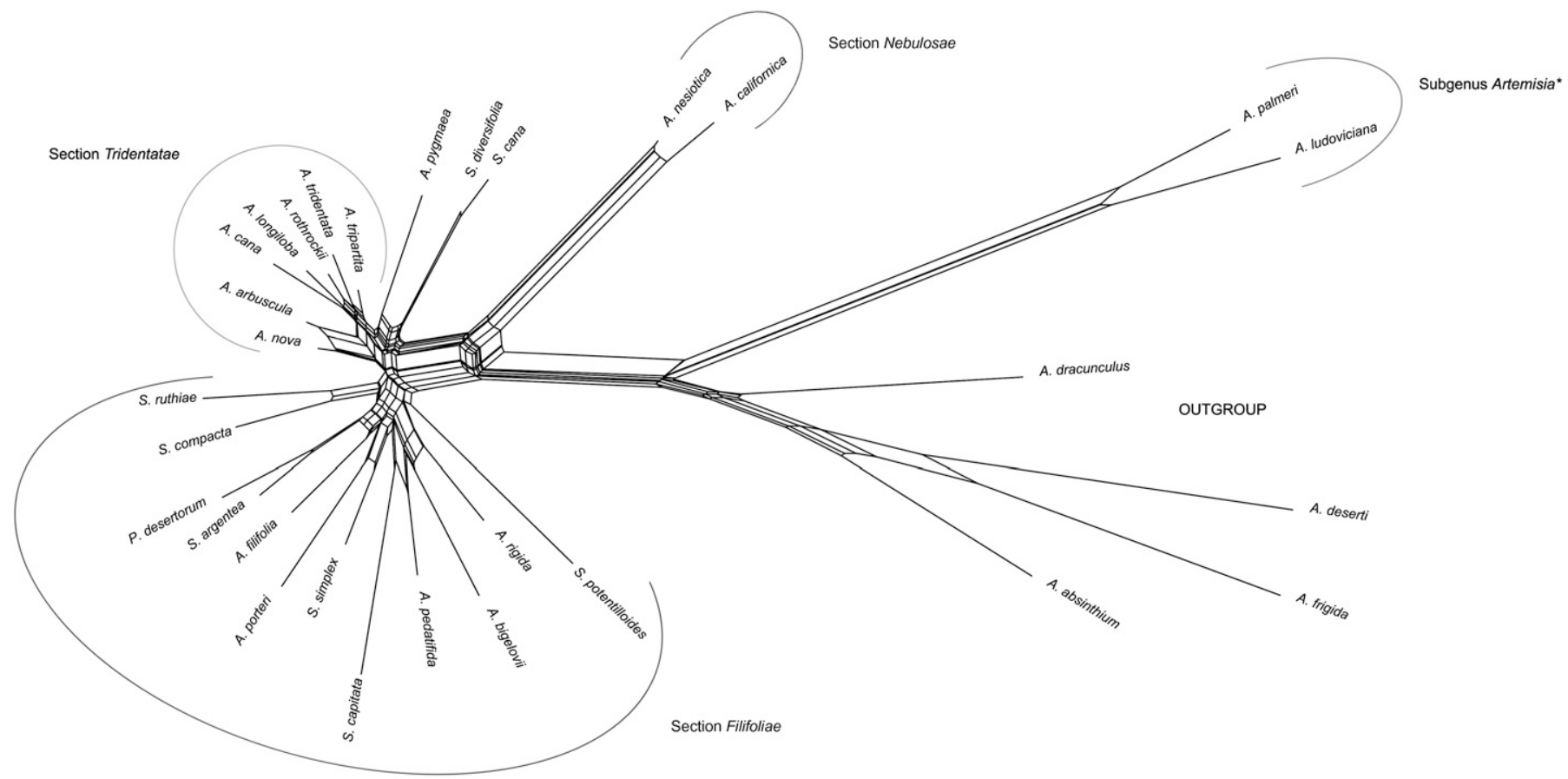

Fig. 3. Neighbor-net based on ITS+ETS sequences from the reduced set (subspecific and putative hybrid entities excluded) with uncorrected pdistances. Scale bar indicates number of expected changes. Asterisk (*) indicates North American endemic.

or recombination could be factors explaining differences in evolutionary rates of these regions as well. Moreover, the ILD test is also prone to inaccurate estimations of incongruence if the data sets are very different in size (Dowton and Austin, 2002; Li et al., 2007), as in the case of our study (653 vs. 1624 bp in the ITS+ETS reduced data set). Additionally, both of the combined ITS+ETS phylogenetic trees had better resolution than when the sequences were analyzed separately, an approach that has also been used to increase phylogenetic resolution in other plant groups (Whitten et al., 2000; Hall et al., 2002; Hoggard et al., 2004). The chloroplast data set (both regions, gaps coded) was not combined with the nuclear one because of some conflicts and also because it slightly lowered the phylogenetic resolution of the ITS+ETS data set. Nevertheless, the chloroplast combined sequence tree is shown (Appendix S8, see Supplemental Data with the online version of this article), as it supports monophyly of the subgenus Tridentatae and illustrates some interesting associations.

Model selection and Bayesian analysis-Both AIC and hLRT criteria (implemented in MrModeltest 2.3; Nylander, 2004) agreed on the model GTR+I+G (General Time Reversible model, with gamma-distributed site-to-site variation and a proportion of invariable sites) for both nuclear data sets ("sagebrushes" and global). For the chloroplast data set, hLTR fit the model F81+I+G and AIC fit GTR+I+G. No inconsistencies were detected between the resulting trees. Therefore we show only the results obtained with the AIC model, as this approach presents several advantages over the hLRTs for model selection, including the simultaneous comparison of nested or nonnested models, the accounting for model selection uncertainty, and the ability to allow model-average inference (Posada and Buckley, 2004). Midpoint rooted phylograms are shown in Figs. 1, 2, and S8 (see Supplemental Data with the online version of this article), with PP values $>0.5$ above branches.

Parsimony analysis - Table 3 summarizes the data related to trees in Figs. 1, 2, and S2 (bootstrap support [BS] $>50 \%$ below branches; see Supplemental Data with the online version of this article), including the characteristics and nucleotide substitution models selected for each data set.

Genome size assessments-Newly generated genome size data are presented in Table 4. These are the first reports for Sphaeromeria. At the diploid level, values show a 1.5-fold variation. The lower value is for the diploid Sphaeromeria ruthiae A. H. Holmgren, L.M. Shultz et Lowrey (6.20 pg), and the upper value is for the tetraploid $S$. potentilloides A. Heller (15.12 pg). The measurements were of overall good quality, with a mean HPCV (half peak coefficient variation) of $0.71 \%$ for the studied species and $3.55 \%$ for the internal standard.

Monoploid genome size data have been used to discriminate between clades in the subgenus, as was done previously between subgenera (Appendix S9, see Supplemental Data with the online version of this article; data from Garcia et al., 2004, 2008) and to take advantage of the complete data for all the species in the present analysis. Comparisons have been done only between clades $\mathrm{C}$ and $\mathrm{D}$ (Fig. 1) because of the reduced sample size of clade $\mathrm{E}$ ( 2 species), which did not allow its inclusion in 
TABLE 3. Summary of sequence data from ITS+ETS, and $\operatorname{trn} S^{\mathrm{GCU}}-\operatorname{trn} C^{\mathrm{GCA}_{+}}$ $\operatorname{trn} S^{\mathrm{UGA}}-\operatorname{trnf} M^{\mathrm{CAU}}$. Ensemble consistency and homoplasy indexes are calculated excluding uninformative characters.

\begin{tabular}{lccc}
\hline \hline Data set & $\begin{array}{c}\text { ITS+ETS } \\
\text { (global) }\end{array}$ & $\begin{array}{c}\text { ITS+ETS } \\
\text { (reduced) }\end{array}$ & $\begin{array}{c}\text { trnS-C+ trnS-fM } \\
\text { (reduced) }\end{array}$ \\
\hline Number of taxa & 152 & 42 & 42 \\
Total characters & 862 & 2278 & 1918 \\
Number of informative characters & 260 & 319 & 27 \\
Missing data codified as "N" (\%) & 1.55 & 1.03 & 0.89 \\
Gaps codified as "-" (\%) & 5.99 & 27.03 & 6.74 \\
Tree length (number of steps) & 1451 & 839 & 138 \\
Range of divergence: ingroup- & $2.17-13.35$ & $29.49-51.11$ & $0.55-1.03$ \\
$\quad$ outgroup (\%) & & & \\
Range of divergence: ingroup (\%) & $0-10.16$ & $0.33-50.22$ & $0-0.65$ \\
Ensemble consistency index (CI) & 0.390 & 0.501 & 0.717 \\
Ensemble retention index (RI) & 0.793 & 0.599 & 0.512 \\
Homoplasy index (HI) & 0.610 & 0.499 & 0.283 \\
Rescaled consistency index (RC) & 0.309 & 0.300 & 0.368 \\
Nucleotide substitution model AIC & GTR+I+G & GTR+I+G & GTR+I+G \\
\multicolumn{1}{c}{ hLTR } & GTR+I+G & GTR+I+G & F81+I+G \\
\hline
\end{tabular}

statistical analyses. After testing for normality (with a negative result), we decided to use the nonparametric Mann-Whitney test, which gave a statistically significant difference $(\mathrm{U}=$ 159.50, $\mathrm{df}=1, P=0.005)$ between monoploid genome sizes of clades $\mathrm{C}$ and $\mathrm{D}(1 \mathrm{C} x$, Fig. 1). Clade $\mathrm{C}$ (corresponding to section Tridentatae) has the largest mean genome size value: $1 \mathrm{C} x=$ 4.46 vs. $1 \mathrm{C} x=3.92$, respectively, for clades $\mathrm{C}$ and $\mathrm{D}$.

\section{DISCUSSION}

Description and delimitation of subgenus Tridentatae and genome size differences between sections-By and large, results (Fig. 1) are consistent with previous work on the whole genus, which characterized a North American endemic group, including species from subgenus Tridentatae and the other genera Picrothamnus and Sphaeromeria (Watson et al., 2002; Vallès et al., 2003; Sanz et al., 2008) in the same clade. However, because of incomplete sampling, these earlier authors were cautious about subsuming these in Tridentatae. On the basis of the phylogenetic relations presented in this study, we support a wider concept of subgenus Tridentatae, enlarging its traditional circumscription and building on the recent revision by Shultz (2009; see Table 1). In her monograph, Shultz (2009) recognized two sections: section Tridentatae (with homogamous capitula and including all the classically considered members of the subgenus, 10 species) and section Nebulosae (with heterogamous capitula, created to accommodate $A$. californica Less., A. filifolia Torr., and A. nesiotica P. H. Raven, species placed within the Tridentatae clade in independent molecular analyses).

Our nuclear (ITS+ETS) molecular phylogenetic reconstruction of Tridentatae and allies (Fig. 1) shows that all the North American endemics are grouped together (clade A, PP $=1.0$, BS $=91 \%$ ). The chloroplast tree (Fig. S2, see Supplemental Data with the online version of this article) also resolves the same clade (clade A) but with nonsignificant statistical support $(\mathrm{PP}=0.79, \mathrm{BS}=50 \%)$. We define what we consider subgenus Tridentatae at clade $\mathrm{B}$, both in the nuclear $(\mathrm{PP}=1.0, \mathrm{BS}=98 \%)$ and in the chloroplast $(\mathrm{PP}=0.99)$ reconstructions, therefore expanding subgenus Tridentatae to include some species previously treated in other subgenera. The sister group, highly supported in the nuclear phylogeny $(\mathrm{PP}=1.0, \mathrm{BS}=100 \%)$ and in the chloroplast one as well ( $\mathrm{PP}=1.0, \mathrm{BS}=92 \%)$, is composed of two North American endemic species of subgenus Artemisia, A. ludoviciana Nutt. and A. palmeri, which were included in Watson et al.'s (2002) phylogenetic treatment as the "A. vulgaris group".

Sections and unranked species-Our description of subgenus Tridentatae is based on the nuclear reconstruction (Fig. 1), since the chloroplast phylogeny is basically unresolved, only well defining the limits of the subgenus. The first clade (C, PP = 0.99 ) is our section Tridentatae, e.g., the Tridentatae sensu stricto or Tridentatae core as recognized by Garcia (2007) and Garcia et al. (2007). Section Tridentatae is clearly a natural group, morphologically homogeneous and geographically defined; it is monophyletic, with all the species within this clade being typical Tridentatae members, all shrubby plants with homogamous capitula and whose placement has never been in question. This section is equivalent to section Tridentatae sensu Shultz (2009) with the exclusion of A. bigelovii, A. pygmaea, and $A$. rigida. These species, which have been classically included in the subgenus, have been the subject of taxonomic controversy, with many studies with different research emphases (morphological, ecological, cytogenetic) proposing either their inclusion or exclusion (discussed later). Section Tridentatae has also two particularities with respect to the rest of the tree: on the one hand, it is the group in which polyploidy is most frequent (note the squares in Fig. 1); on the other hand, this section presents shorter branches.

When Shultz (2009) erected the new section Nebulosae to accommodate three species that in previous molecular research had appeared closely related within subgenus Tridentatae, she chose the name both in reference to the still uncertain or "nebulous" boundaries of the proposed section and to allude to the range of those species forming a geographical cloud-like bordering of the Intermountain Region, the core distribution area for section Tridentatae. She also noted that species from Sphaeromeria and maybe other non-Tridentatae Artemisia might be part of the "nebulous complex" but did not propose a transfer until more species of these groups were studied with molecular data. The current study meets this requirement and expands knowledge not only for all but one Sphaeromeria species but also for the monotypic Picrothamnus and for other taxa of uncertain position. Following this reasoning, the next clade with significant support (clade D, PP $=0.99$ ), a grouping of several North American endemic Artemisia, Picrothamnus, and Sphaeromeria, would correspond to an expansion of this "nebulous complex" concept. However, it would be taxonomically incorrect to use the name of section Nebulosae for clade D, since the type species selected by Shultz in describing this section is A. californica, which is not included in this clade but which forms a separate, well-supported grouping with A. nesiotica (discussed later). Therefore, the name "Nebulosae" should be conserved for the section keeping the type species (W. Greuter, Botanical Garden and Botanical Museum, Berlin, personal communication), and in consequence, a new section is proposed, based in the unranked infraspecific taxon Filifoliae Rydb. (with type species A. filifolia and including also A. pedatifida), covering the clade D composition. The diagnostic criteria for this section are the same as stated by Rydberg (1916) when describing Filifoliae. The circumscription of sections Nebulosae and Tridentatae and the description of section Filifoliae, as 
TABLE 4. Genome size and other karyological data of the species of Sphaeromeria assessed. In all cases, the standard used for flow cytometry assays was Petunia hybrida 'PxPc6'.

\begin{tabular}{|c|c|c|c|c|c|c|c|}
\hline Species & P. L. & $2 \mathrm{C}(\mathrm{pg})$ & S. D. & $1 \mathrm{C} x(\mathrm{pg})$ & $2 \mathrm{C}(\mathrm{Mbp})$ & HPCV sample & HPCV standard \\
\hline Sphaeromeria argentea & 2 & 9.26 & 0.21 & 4.63 & $9,056.3$ & 1.02 & 3.01 \\
\hline Sphaeromeria cana & 2 & 9.2 & 0.47 & 4.60 & $8,997.6$ & 0.73 & 4.62 \\
\hline Sphaeromeria capitata & $2 *$ & 6.21 & 0.07 & 3.11 & $6,073.4$ & 1.60 & 3.37 \\
\hline Sphaeromeria compacta & 2 & 9.28 & 0.16 & 4.64 & $9,075.8$ & 0.36 & 2.70 \\
\hline Sphaeromeria diversifolia & 2 & 8.2 & 0.28 & 4.10 & $8,019.6$ & 0.49 & 2.90 \\
\hline Sphaeromeria potentilloides & $4 *$ & 15.12 & 0.21 & 3.78 & $14,787.4$ & 0.25 & 6.06 \\
\hline Sphaeromeria ruthiae & 2 & 6.2 & 0.25 & 3.10 & $6,063.6$ & 0.73 & 3.27 \\
\hline Sphaeromeria simplex & $2 *$ & 7.15 & 0.28 & 3.58 & $6,992.7$ & 0.51 & 2.53 \\
\hline
\end{tabular}

Note: P. L. = Ploidy level; $2 \mathrm{C}(\mathrm{pg})=$ nuclear DNA content in pg; S. D. = standard deviation; $1 \mathrm{C} x(\mathrm{pg})=$ monoploid genome size (nuclear DNA content per haploid chromosome set); 2C (Mbp) = nuclear DNA content in Mbp (1 pg = $978 \mathrm{Mbp}$; Doležel et al., 2003); HPCV = half peak coefficient of variation.

*Ploidy levels inferred from genome size data.

well as the combination of some Sphaeromeria species, have been presented in a separate taxonomic note (Garcia et al., in press).

The composition of section Filifoliae is diverse, including (1) species previously considered to be members of section Tridentatae (A. bigelovii and A. rigida); (2) some Artemisia (A. pedatifida Nutt., A. porteri Cronquist, and A. filifolia) and the monotypic genus Picrothamnus; all these were formerly placed in subgenus Dracunculus on the basis of their heterogamous capitula with functionally staminate disc florets; and finally, (3) most species from Sphaeromeria. From the morphological point of view, most of these species have in common a shrubby habit (though several Sphaeromeria are short herbaceous perennials), the presence interxylary cork, and heterogamous capitula (excepting $A$. rigida, with homogamous flower heads).

The third differentiated group in clade $\mathrm{B}$ is clade $\mathrm{E}(\mathrm{PP}=1.0$, $\mathrm{BS}=100 \%$ ), including the species A. californica and A. nesiotica, formerly considered members of subgenus Artemisia (Shultz, 2006a). This clade is also strongly supported by the chloroplast reconstruction (Fig. S2, see Supplemental Data with the online version of this article; $\mathrm{PP}=1.0)$. These species are separated from the other North American endemic members of subgenus Artemisia (A. ludoviciana and A. palmeri). They are also distinct from the remainder geographically, as they exclusively inhabit coastal or island regions of the California shore. Shultz (2009) placed them in the new section Nebulosae (characterized by heterogamous capitula) together with A. filifolia; however, the present data do not support this grouping, as previously discussed. Given the close affinity between both California species (indeed, A. nesiotica has been described previously as a subspecific taxon of $A$. californica, A. californica Less. var. insularis Munz) and their mild distinctiveness from other Artemisia taxa (shrubby habit, wandlike stems), section Nebulosae should be kept for the two California species, $A$. californica and A. nesiotica, but excluding A. filifolia.

Finally, four species (A. argilosa, A. pygmaea, S. cana [D. C. Eaton] A. Heller, and $S$. diversifolia [D. C. Eaton] Rydb.), though clearly members of subgenus Tridentatae, are not included in any section, as they do not reside in any strongly supported clade. The position of A. argilosa and A. pygmaea as a potential sister group to section Tridentatae was suggested previously (Garcia, 2007; Garcia et al., 2007), but the present analysis does not fully support this suggestion. The placement of these two Sphaeromeria species is additional evidence for the artificial nature of this genus, as discussed later. By and large, the splits graph analysis (Fig. 3) may be illustrative of species relations in this group, in which species from section Tridentatae appear closely interrelated, species from section Filifoliae are more loosely clustered and much more divergent, and species of section Nebulosae are clearly apart from all other species, with the unranked taxa clustering somewhere in between. These groupings also suggest an assemblage in which hybridization might be a common evolutionary phenomenon.

Genome size comparisons have been performed between sections Tridentatae and Filifoliae (but not section Nebulosae because of its reduced sample size), resulting in a statistically significant difference between sections $(P=0.0065)$; section Tridentatae has the largest mean genome size $(1 \mathrm{C} x)$. This is consistent with a larger mean genome size value reported for subgenus Tridentatae with respect to the other Artemisia subgenera (Garcia et al., 2004, 2008). Moreover, as seen in the bar diagram of Fig. 1, genome size values are much more heterogeneous for section Filifoliae than for section Tridentatae, consistent with the heterogeneous composition of section Filifoliae (Figs. 1 and 3).

Interspecific relations within sections-Many of the groupings within the different supported clades suggest associations between unrelated species. These anomalous groupings may be a response to the geographical proximity of populations that facilitated hybridization and/or introgression processes (reticulation) that complicate the understanding of phylogenetic relations. Although our approach, as others' (Kornkven et al., 1998, 1999; Watson et al., 2002; Shultz, 2006a; Riggins, 2008), fails to discriminate any groupings, previous taxonomic treatments (Ward, 1953; Beetle, 1960; Shultz, 1983) have suggested the existence of distinctive sagebrush lineages (Table 1), in which the species A. tridentata Nutt., A. arbuscula, and $A$. nova A. Nelson appear closely related, as they do in clades c1 and c2 (Fig. 1). The close relation between these three species has been foreshadowed by several nomenclatural rearrangements, as $A$. nova has been described as a subspecies of $A$. tridentata and also as a subspecies of A. arbuscula, which, likewise, has been described as a subspecies of A. tridentata.

Genera Sphaeromeria and Picrothamnus: the need for a nomenclatural revision-Sphaeromeria and Picrothamnus are the only genera with an exclusive North American distribution within Artemisiinae (Bremer and Humphries, 1993; Oberprieler et al., 2007). Previous phylogenetic approaches (Watson et al., 2002; Vallès et al., 2003; Lowrey and Shultz, 2006; Shultz, 2006b; 
Riggins, 2008; Sanz et al., 2008) did not fully resolve their actual placement, but all noted their close relation to Artemisia, given that in most of these authors' phylogenies, Sphaeromeria and Picrothamnus constituted part of the Artemisia clades. From the composition of section Filifoliae in the nuclear analysis (Fig. 1, D), that of clade B in the chloroplast one (Fig. S2, see Supplemental Data with the online version of this article), and their placement in the global reconstruction (Fig. 2), it seems clear that neither Sphaeromeria nor Picrothamnus should be considered independent genera. Moreover, these species appear embedded in the subgenus Tridentatae clade. Additionally, in the case of Sphaeromeria, species are spread in segregated clades within Tridentatae, an indication, as pointed previously, that Sphaeromeria is an artificial, polyphyletic genus.

The presence of mostly corymbiform inflorescences rather than the paniculiform, racemiform, or spiciform arrays more typical of Artemisia is probably the most visible trait distinguishing Sphaeromeria from most Artemisia (Fig. 1, photographs), particularly from the North American endemics, though corymbs may have evolved multiple times in different lineages of the genus and among its Eurasian allies. Because of their morphological appearance, many species of Sphaeromeria had been classified previously as members of Tanacetum $\mathrm{L}$. (see Shultz, 2006a), though some of them had been segregated in the monotypic genera Chamartemisia Rydb. (Sphaeromeria compacta [H. M. Hall] A. H. Holmgren, L. M. Shultz et Lowrey) and Vesicarpa Rydb. (Sphaeromeria potentilloides [A. Gray] A. Heller). However, the work of Holmgren et al. (1976) treated Sphaeromeria closer to Artemisia than to Tanacetum on the basis of morphological traits besides inflorescence types; results consistent with these observations were obtained with RAPD analysis (McArthur et al., 1998b) and later were confirmed by other molecular work (Watson et al., 2002; Riggins, 2008). Genome size data for Sphaeromeria species are quite heterogeneous, even at the same ploidy level (Fig. 1 and Table 4), which is additional evidence of the heterogeneity of the species constituting this genus and its likely artificial nature. On a larger taxonomic scale, however, the values at diploid and tetraploid levels are consistent with subtribe Artemisiinae genome size data (Garcia et al., 2004, 2008; Pellicer et al., 2010a).

Morphological similarity of Picrothamnus desertorum with Artemisia members is clearer. This taxon was first described by Nuttall (1841) but later placed in Artemisia as A. spinescens D. C. Eaton (1871), in section Dracunculus. Hall and Clements (1923) also considered it a member of Dracunculus because of its functionally male central florets with reduced ovaries and fused style-branches, and they stated that features such as the villous pubescence of achenes and corollas or the characteristic spiny habit could not be contemplated at generic or even sectional value. Later, however, Bremer and Humphries (1993) regarded these traits as autapomorphies of the species; although considered a member of subgenus Dracunculus on the basis of floral morphology, its phylogenetic position (in this study and previous ones) within an expanded subgenus Tridentatae is clear. This point brings into serious question the validity of floral morphology as a defining subgeneric character; apparently homogamous flower heads have appeared several times during the evolution of Artemisia (Watson et al., 2002; Sanz et al., 2008).

The results of this study coupled with previous work recommend a nomenclatural redefinition of these genera, subsuming their species within Artemisia subgenus Tridentatae section Filifoliae or unranked within the subgenus. Picrothamnus desertorum should be best recognized as Artemisia spinescens, a name that, in addition, constitutes an appropriate description of the species. Indeed, this treatment was yet followed by some authors (L. M. Shultz, personal communication). In the case of Sphaeromeria, we are proposing the new names in a taxonomic revision of sections of the subgenus (Garcia et al., in press).

Excluded species from sect. Tridentatae-The three species (Artemisia bigelovii, A. pygmaea, A. rigida) excluded from section Tridentatae (or the Tridentatae core) consist of three interesting cases. Their phylogenetic position in the subgenus has been questioned by several authors on the basis of morphological and molecular data. Previous treatment of these species is illustrative of the taxonomic problems accompanying the subgenus that gave impetus to this study.

First is the case of Artemisia bigelovii and its anomalous floral morphology (the only Tridentatae taxon with heterogamous capitula; Hall and Clements, 1923; Ward, 1953; Shultz, 1983; Ling, 1991, 1995a). Molecular phylogenetic data (Kornkven et al., 1998), essential oil composition (Holbo and Mozingo, 1965; Geissman and Irwin, 1974), and our own results on molecular cytogenetics and genome size (Garcia et al., 2007, 2008) clearly differentiate it from the Tridentatae core. This species generally has been treated as a member of Tridentatae on the basis of many characters, such as wood anatomy, leaf form, karyotype morphology, RAPD genetic markers, and cpDNA restriction site analyses (McArthur et al., 1981, 1998a; Kornkven et al., 1999). However, our present results add evidence for the segregation of $A$. bigelovii from section Tridentatae, though retained in the subgenus Tridentatae.

The second case, Artemisia rigida, is a species well adapted to particular habitats and displays specialized morphological and anatomical modifications to extreme conditions of aridity (Hall and Clements, 1923; Shultz, 1983; McArthur and Stevens, 2004). Its distinctiveness gave rise to its separate placement in another section within subgenus Seriphidium, sect. Rigidae Rydb. (Rydberg, 1916). Holbo and Mozingo's (1965) chromatographic characterization also pointed to its exclusion from the Tridentatae core, as do our findings with in situ hybridization, genome size studies (Garcia, 2007; Garcia et al., 2008), and the present results, which place it apart from the core of the sagebrushes and suggest a tight relation with $A$. bigelovii $(\mathrm{PP}=1.0, \mathrm{BS}=79 \%$, Fig. 1). In this line, Kornkven et al. (1999) stated that $A$. rigida may have diverged early in the evolution of the subgenus, on the basis of its sister position to the core Tridentatae species in their phylogeny, in addition to its morphological specialization. Shultz's (2009) analysis on pollen morphology suggested an alliance with A. cana and A. tripartita (sharing elongated pollen grains, the three of them), which may represent a xeromorphic specialization.

The last case is pygmy sagebrush, Artemisia pygmaea, a dwarf shrub with different leaf morphology and larger seeds compared with the other Tridentatae and considered the most xerophytic taxon in the subgenus (Cronquist, 1994; McArthur and Stevens, 2004). It is a relatively uncommon species, limited to limestone soils in the desert areas of central and western Utah, eastern $\mathrm{Ne}$ vada, and northern Arizona (Ward, 1953). On the basis of specialized ecologically adaptive features, Rydberg (1916) placed A. pygmaea in a separate section (sect. Pygmaea Rydb.). Essential oil composition (Holbo and Mozingo, 1965; Geissman and Irwin, 1974), some differences in karyotype morphology (Garcia et al., 2007), and a significantly larger genome size (Garcia et al., 2008) also differentiate it from most members of section 
Tridentatae. Previous molecular biology studies have placed this species as sister to the other Tridentatae (Kornkven et al., 1998; Watson et al., 2002), and our data also place it as a sister to the core Tridentatae, along with two Sphaeromeria species.

Each of the three species, Artemisia bigelovii, A. pygmaea, and $A$. rigida, while not placed in section Tridentatae, are still included in subgenus Tridentatae.

A broader approach: circumscription of the New World Artemisia species in the framework of the genus-With the purpose of not only obtaining an adequate phylogenetic delimitation of the North American subgenus Tridentatae but also of other New World endemic Artemisia, we conducted a larger phylogenetic analysis of the genus. In this analysis (global data set, Fig. 2) the western North American and other New World endemic Artemisia are resolved exclusively in clade A $(\mathrm{PP}=$ $1.0, \mathrm{BS}=71 \%$ ). Within this clade, clade B (supported by a PP = $0.95, \mathrm{BS}=54 \%$ ) is constituted by species from subgenera Artemisia and Absinthium, including some North American; clade $\mathrm{C}(\mathrm{PP}=1.0$ and $\mathrm{BS}=85 \%)$ contains the majority of New World endemics. Given that American species appear in two different clades, our data indicate that New World endemics are of multiple origins, supporting the hypothesis by Tkach et al. (2008) of several migrations from Asia to North America. Clade $\mathrm{D}(\mathrm{PP}=1.0$ and $\mathrm{BS}=90 \%)$ within the large clade A, is constituted by subgenus Seriphidium species that also have a close relation with subgenus Artemisia, suggesting that both Tridentatae and Seriphidium could have their ancestry in species from subgenus Artemisia.

In clade $\mathrm{B}$, the North American endemics from subgenus Artemisia (both A. ludoviciana subspecies, A. mexicana Willd. A. michauxiana Besser, and $A$. palmeri) appear in a highly supported clade $\left(\mathrm{b}_{1}, \mathrm{PP}=1.0, \mathrm{BS}=100 \%\right)$ together with $A$. hultenii Maximova and A. tilesii Ledeb. (also called A. hultenii subsp. tilesii), also from this subgenus. These latter species are native to Siberia (the type is described from Kamchatka) but are widely distributed in northern North America. It is likely that, given their geographic distribution and phylogenetic position, these species are involved in the origin of A. ludoviciana and relatives (assigned to subgenus Artemisia with their disciform, heterogamous heads and glabrous receptacles, among other defining characteristics). It is also possible that hybridization between Asiatic and American species explains the position of Siberian Artemisia. The sister clade to this grouping $\left(\mathrm{b}_{2}, \mathrm{PP}=1.0\right.$, $\mathrm{BS}=88 \%$ ) constitutes the $A$. vulgaris complex, a group of species from subgenus Artemisia previously pointed out by others (Sanz et al., 2008; Tkach et al., 2008; Pellicer et al., 2010b). Clade $\mathrm{B}$ is finally completed with a group $\left(\mathrm{b}_{3}\right)$ constituted by subarctic species (from Siberia and Alaska) currently classified in subgenus Absinthium.

It is evident, not only from this clade but also from the rest of the tree, that subgenera Artemisia and Absinthium are interrelated and their taxonomic separation is probably artificial. Comprehensive studies of the whole genus have provided results intermixing subgenera Artemisia and Absinthium and placing species within phylogenetic trees irrespective of putative $A r$ temisia/Absinthium classical lineages (Torrell et al., 1999; Vallès et al., 2003; Riggins, 2008; Sanz et al., 2008; Tkach et al., 2008), another sign that both should be placed in a unified subgenus Artemisia. Nevertheless, it seems that most subgenus Absinthium members of this sampling do form clade $\mathrm{E}$ in the global analysis, with only some subgenus Artemisia members intermixed.
Clade $\mathrm{C}(\mathrm{PP}=1.0, \mathrm{BS}=85 \%)$ includes all the species previously described in subgenus Tridentatae with the difference, with respect to the former analysis (reduced data set), that section Tridentatae is not monophyletic. Both Sphaeromeria and Picrothamnus appear again subsumed in the same clade, thus supporting their placement in subgenus Tridentatae. It is likely that (1) the inclusion of many other nonendemic Artemisia, (2) the exclusion of subspecific and presumed hybrid entities, and (3) the shorter length of the ETS region used for this analysis with respect to the previous analysis blur relations within this subgenus. But on the other hand, the inclusion of additional nonendemic Artemisia may also constitute a clue about the possible ancestors of Tridentatae and other New World relatives. It has been suggested that subgenus Seriphidium was the closest relative to Tridentatae because of a synapomorphy of both subgenera, the homogamous capitula (Ward, 1953; Beetle, 1960; Ling, 1991, 1995a, b). An alternative scenario was proposed by McArthur and Plummer (1978) and McArthur et al. (1981), in which subgenus Artemisia could be basal to Tridentatae, as supported by our analysis. The most closely related group to clade C (New World Tridentatae and other endemics) is clade $\mathrm{B}$, consisting in major part of species from subgenus Artemisia. In addition, some of the non-Tridentatae species in clade $\mathrm{C}$ also belong to subgenus Artemisia: A. comata Rydb., A. flava Jurtsev, A. furcata M. Bieb., and A. hyperborea Rydb. are Beringian (A. furcata being the only one with an amphi-Beringian range with extensions further south in Eurasia and North America), which fits with a likely biogeographic history of the New World species deriving from an ancestral Artemisia (subgenus) stock (map in Fig. 2).

Another clade of species consists of the South American endemics $\left(\mathrm{c}_{1}, \mathrm{PP}=1.0, \mathrm{BS}=100 \%\right)$. These are interesting, since the genus is not particularly abundant in the southern Hemisphere (Bremer and Humphries, 1993). Because these species display the typical capitula traits related to subgenus Artemisia, they have been considered as such, though previously one of them had been classified as a member of Seriphidium (de Candolle, 1837; Bremer and Humphries, 1993). Artemisia echegarayi Hieron, A. mendozana DC., and A. mendozana DC. var. paramilloensis F. A. Roig et J. A. Ambrosetti are endemic to Argentina; A. copa Phil. occurs in Argentina, Chile, the West Indies, and Mexico (Ling, 1995a). Given that some Tridentatae species are also present in Mexico and considering the position of the South American endemics in the phylogeny, it is likely that sagebrushes may be involved in the origin of this group, with $A$. copa being the sister species ( $\mathrm{PP}=$ $1.0, \mathrm{BS}=100 \%)$ to the other South American endemics (except A. magellanica Sch. Bip., as indicated later). Although there is no clear sister-group relation with any other specific taxon in this clade, the position of the South American Artemisia within subgenus Tridentatae is clear, supporting a recent hypothesis about the origin of these species (Pellicer et al., 2010b). There is another Patagonian species, A. magellanica, of a clearly different phylogenetic origin than the $\mathrm{c}_{1}$ group. This species is closely related to A. biennis Willd. ( $\mathrm{PP}=1.0$, $\mathrm{BS}=100 \%)$ and to species of subgenus Dracunculus (PP = $1.0, \mathrm{BS}=84 \%$ ), suggesting that both in North and South America, the various endemic Artemisia species have their origins in different subgenera.

Conclusions - The results provided by this phylogenetic study call for a redefinition of subgenus Tridentatae to include 
other western North America endemics. An expanded circumscription of the subgenus is proposed, dividing it into three sections: Tridentatae, Filifoliae, and Nebulosae, the last two erected to accommodate species and other genera that have been considered closely related, but in undefined ways, to the core sagebrushes. These conclusions have taxonomic-nomenclatural consequences. The genera Sphaeromeria and Picrothamnus should be treated as Artemisia species, and new nomenclatural combinations have been proposed (Garcia et al., in press) in this sense.

Relationships between species within the different sections are, however, difficult to interpret. Because of absence of reproductive barriers, reticulate events involving different kinds of hybridization among taxa (allopolyploidy, homoploid hybrid formation, introgression) may be abundant, giving birth to multiple and recurrent combinations that have surely contributed to the blurring of relations among taxa and have enhanced the well-deserved reputation of this group of being taxonomically difficult, even though these processes also may contribute to its evolutionary success, current species richness, and diversity. A different approach, probably involving studies at the population level, would be useful in elucidating particular interspecific relations in this group.

The phylogenetic position of the Beringian species from subgenus Artemisia within the Tridentatae clade and that of the other North American endemics in another clade of subgenus Artemisia suggest that the ancestors of the New World species should be found in subgenus Artemisia and that there have been at least two colonization events from Asia to America, giving rise to the North American endemics (map in Fig. 2).

For the South American (A. copa, A. echegarayi, A. mendozana var. mendozana, and A. mendozana var. paramilloensis) and the Beringian (A. comata, A. flava, A. furcata, and A. hyperborea) species, we question their transfer to subgenus Tridentatae. A more complete study should be performed on them, including morphological and ecological aspects as well as analysis of more DNA regions. In this sense, we prefer keeping the concept of subgenus Tridentatae sensu Shultz (2009): a New World alliance of shrubby species endemic to western North America.

\section{LITERATURE CITED}

Acevedo-Rosas, R., K. Cameron, V. Sosa, and S. Pell. 2004. A molecular phylogenetic study of Graptopetalum (Crassulaceae) based on ETS, ITS, RPL16, and trnlF nucleotide sequences. American Journal of Botany 91: 1099-1104.

AKaIKe, H. 1974. A new look at the statistical model identification. IEEE Transactions on Automatic Control 19: 716-723.

Álvarez, I., AND J. F. Wendel. 2003. Ribosomal ITS sequences and plant phylogenetic inference. Molecular Phylogenetics and Evolution 29: 417-434.

BALDWIN, B. G., AND S. MARKos. 1998. Phylogenetic utility of the external transcribed spacer (ETS) of 18S-26 rDNA: Congruence of ITS and ETS trees of Calycadenia (Compositae). Molecular Phylogenetics and Evolution 10: 449-463.

Baldwin, B. G., M. J. Sanderson, J. M. Porter, M. F. Wojciechowski, C. S. CAmpbell, And M. J. Donoghue. 1995. The ITS region of nuclear ribosomal DNA: A valuable source of evidence on angiosperm phylogeny. Annals of the Missouri Botanical Garden 82: 247-277.

Beetle, A. A. 1960. A study of sagebrush, the section Tridentatae of Artemisia. Bulletin 368. University of Wyoming Experiment Station, Laramie, Wyoming, USA.
Bena, G., M. F. Jubier, I. Olivieri, And B. Lejeune. 1998. Ribosomal external and internal transcribed spacers: Combined use in the phylogenetic analysis of Medicago (Leguminosae). Journal of Molecular Evolution 46: 299-306.

Bremer, K. 1994. Asteraceae: Cladistics and classification. Timber Press, Portland, Oregon, USA.

Bremer, K., And C. J. Humphries. 1993. Generic monograph of the Asteraceae-Anthemideae. Bulletin of the National History Museum of London (Botany) 23: 71-177.

Cronquist, A. 1994. Asterales. In A. H. Cronquist, N. H. Holmgren, J. L. Reveal, and P. K. Holmgren [eds.], Intermountain flora, vol. 5. New York Botanical Garden, Bronx, New York, USA.

DAvis, O. K., AND B. ELLIS. 2010. Early occurrence of sagebrush steppe, Miocene (12 Ma) on the Snake River Plain. Review of Palaeobotany and Palynology 160: 172-180.

de Candolle, A. P. 1837. Prodromus systematis naturalis regni vegetabilis. Paris, France.

Demesure, B., N. Sodzi, And R. J. Petit. 1995. A set of universal primers for amplification of polymorphic non-coding regions of mitochondrial and chloroplast DNA in plants. Molecular Ecology 4: 129-131.

Doležel, J., J. Bartoš, H. Voglmayr, and J. Greilhuber. 2003. Nuclear DNA content and genome size of trout and human. Cytometry A 51: 127-128.

Dowton, M., AND A. D. Austin. 2002. Increased congruence does not necessarily indicate increased phylogenetic accuracy-The behaviour of the incongruence length difference test in mixed-model analyses. Systematic Biology 51: 19-31.

DoyLE, J. J., AND J. L. DoYLE. 1987. A rapid DNA isolation procedure for small quantities of fresh leaf tissue. Phytochemistry Bulletin 19: 11-15.

Eaton, D. C. 1871. Artemisia spinescens D.C.Eaton. In Botany (Fortieth Parallel). Vol 5. Washington DC, USA.

Englund, M., P. Pornpongrungrueng, M. H. G. Gustafsson, And A. Anderberg. 2009. Phylogenetic relationships and generic delimitation in Inuleae subtribe Inulinae (Asteraceae) based on ITS and cpDNA sequence data. Cladistics 25: 319-352.

Estes, J. R. 1969. Evidence for autopolyploid evolution in the Artemisia ludoviciana complex of the Pacific Northwest. Brittonia 21: 29-43.

Farris, J. S., M. Källerssö, A. G. Kluge, AND C. Bult. 1994. Testing significance of incongruence. Cladistics 10: 315-319.

Felsenstein, J. 1985. Confidence limits on phylogenies: An approach using the bootstrap. Evolution; International Journal of Organic Evolution 39: 783-791.

Ferguson, C. W. 1964. Annual rings in big sagebrush, Artemisia tridentata. In Papers of the Laboratory of Tree-Ring Research, no. 1. University of Arizona Press, Tucson, Arizona, USA.

Funk, V. A., A. Susanna, T. F. Stuessy, and H. Robinson, [eds.]. 2009. Classification of Compositae. In Systematics, evolution, and biogeography of Compositae. 171-192. Sheridan Books, Inc., Ann Arbor, Michigan, USA.

Galbraith, D. W., K. R. Harkins, J. M. Maddox, N. M. Ayres, D. P. Sharma, AND E. FiroozABADY. 1983. Rapid flow cytometric analysis of the cell cycle in intact plant tissues. Science 220: 1049-1055.

GARCIA, S. 2007. Una aproximació a l'estudi de l'evolució i la sistemàtica d'Artemisia i gèneres afins en els àmbits de la citogenètica i filogènia moleculars. Ph.D. dissertation, University of Barcelona, Spain.

Garcia, S., M. Á. Canela, T. Garnatje, E. D. McArthur, J. Pellicer, S. C. SANDERSon, ANd J. Vallès. 2008. Evolutionary and ecological implications of genome size in the North American endemic sagebrushes (Artemisia, subgenus Tridentatae). Biological Journal of the Linnean Society. Linnean Society of London 94: 631-649.

Garcia, S., T. Garnatje, O. Hidalgo, S. Siljak-Yakovlev, and J. VALLÈs. 2007. Extensive ribosomal DNA (18S-5.8S-26S and 5S) colocalization in the North American endemic sagebrushes (subgenus Tridentatae, Artemisia, Asteraceae) revealed by FISH. Plant Systematics and Evolution 267: 79-92.

Garcia, S., T. Garnatje, E. D. McArthur, J. Pellicer, S. SiljakYAKOVLEV, AND J. VALLÈs. 2009. Ribosomal DNA, heterochromatin, and correlation with genome size in diploid and polyploid North 
American endemic sagebrushes (Artemisia, Asteraceae). Genome 52: $1012-1024$.

Garcia, S., M. Sanz, T. Garnatje, A. Kreitschitz, E. D. McArthur, AND J. VALLÈs. 2004. Variation of DNA amount in 47 populations of the subtribe Artemisiinae and related taxa (Asteraceae, Anthemideae): Karyological, ecological, and systematic implications. Genome 47: 1004-1014.

Garcia, S., T. Garnatje, E. D. McArthur, J. Pellicer, S. C. Sanderson, AND J. VALLÈs. In press. Taxonomic and nomenclatural rearrangements in Artemisia subgen. Tridentatae including a redefinition of Sphaeromeria (Asteraceae, Anthemideae). Western North American Naturalist.

Geissman, T. A., AND M. A. Irwin. 1974. Chemical constitution and botanical affinity in Artemisia. In G. Bendz and J. Santesson [eds.], Chemistry in botanical classification, Proceedings of the Twenty-fifth Nobel Symposium, 135-143. Academic Press, New York, New York, USA.

Hall, H. M., AND F. E. Clements. 1923. The phylogentic method in taxonomy. The North American species of Artemisia, Chrysothamnus, and Atriplex. Carnegie Institute of Washington Year Book 326: 1-355.

Hall, J. C., K. J. Sytsma, and H. H. Iltis. 2002. Phylogeny of Capparaceae and Brassicaceae based on chloroplast sequence data. American Journal of Botany 89: 1826-1842.

HALL, T. A. 1999. BioEdit: A user-friendly biological sequence alignment editor and analysis program for Windows 95/98/NT. Nucleic Acids Symposium Series 41: 95-98.

Hidalgo, O., N. Garcia-Jacas, T. Garnatje, K. Romashchenko, A. Susanna, AND S. SiljaK-Yakovlev. 2008. Extreme environmental conditions and phylogenetic inheritance: Systematics of Myopordon and Oligochaeta (Asteraceae, Cardueae Centaureinae). Taxon 57: 769-778.

Hoggard, G. D., P. J. Kores, M. Molvray, and R. K. HJoggard. 2004 The phylogeny of Gaura (Onagraceae) based on ITS, ETS, and trnL-F sequence data. American Journal of Botany 91: 139-148.

Holbo, H. R., And H. N. Mozingo. 1965. The chromatographic characterization of Artemisia section Tridentatae. American Journal of Botany 52: 970-978.

Holmgren, A. H., L. M. Shultz, and T. K. Lowrey. 1976. Sphaeromeria, a genus closer to Artemisia than to Tanacetum (Asteraceae: Anthemideae). Brittonia 28: 252-262.

HuelsenBeCK, J. P., AND F. Roneuist. 2001. MrBayes: Bayesian inference of phylogenetic trees. Bioinformatics (Oxford, England) 17: $754-755$.

Huson, D. J., AND D. BRyant. 2006. Application of phylogenetic networks in evolutionary studies. Molecular Biology and Evolution 23: 254-267.

JEFFreY, C. J. 1995. Compositae systematics 1975-1993. Developments and desiderata. In D. J. N. Hind, C. Jeffrey, and G.V. Pope [eds.], Advances in Compositae systematics, 3-21. Royal Botanic Gardens, Kew, UK.

Kim, K. J., K. S. ChoI, AND R. K. JANSEN. 2005. Two chloroplast DNA inversions originated simultaneously during the early evolution of the sunflower family (Asteraceae). Molecular Biology and Evolution 22: $1783-1792$.

Kornkven, A. B., L. Watson, And J. Estes. 1998. Phylogenetic analysis of Artemisia section Tridentatae (Asteraceae) based on sequences from the internal transcribed spacers (ITS) of nuclear ribosomal DNA. American Journal of Botany 85: 1787-1795.

Kornkven, A. B., L. Watson, And J. Estes. 1999. A molecular phylogeny of Artemisia sect. Tridentatae (Asteraceae) based on chloroplast DNA restriction site variation. Systematic Botany 24: 69-84.

Leitch, I. J., AND M. D. Bennett. 2004. Genome downsizing in polyploid plants. Biological Journal of the Linnean Society. Linnean Society of London 82: 651-663.

Li L., J. Li, J. G. Conran, And X. W. Li (H.-W. Li). 2007. Phylogeny of Neolitsea (Lauraceae) inferred from Bayesian analysis of nrDNA ITS and ETS sequences. Plant Systematics and Evolution 269: 203-221.

Linder, C. R., L. R. Goertzen, B. V. Heuvel, J. Francisco-Ortega, AND R. K. JANSEN. 2000. The complete external transcribed spacer of 18S-26S rDNA: Amplification and phylogenetic utility at low tax- onomic levels in Asteraceae and closely allied families. Molecular Phylogenetics and Evolution 14: 285-303.

Ling, Y. R. 1991. The Old World Seriphidium (Compositae). Bulletin of Botanical Research 11: 1-40.

Ling, Y. R. 1995a. The New World Seriphidium (Bess.) Fourr. In D. Hind and H. Beentje [eds.], Proceedings of the Kew International Compositae Conference, vol I, 283-291. Royal Botanic Gardens, Kew, UK.

LiNG, Y. R. 1995b. On the floristics of Artemisia L. in the world. Bulletin of Botanical Research 15: 1-37.

Ling, Y. R., C. J. Humpries, AND L. M. Shultz. 2006. Seriphidium (Besser) Poljakov. In Ed. Comittee [eds.], Flora of China, vol. 20 (Asteraceae). Science Press, Beijing, China, and Missouri Botanical Garden Press, St. Louis, Missouri, USA. Website: http://flora.huh. harvard.edu/china/mss/volume20/Asteraceae-K-Anthemideae-part1_ coauthoring.htm.

Lowrey, T. K., AND L. M. Shultz. 2006. The genus Sphaeromeria (Asteraceae: Anthemideae). In Editorial Committee [eds.], Flora of North America, vol. 19, Asterales, part 1, 499-502. Oxford University Press, New York, New York, USA.

Marie, D., AND S. C. Brown. 1993. A cytrometric exercise in plant DNA histograms, with $2 \mathrm{C}$ values for 70 species. Biology of the Cell 78 : $41-51$.

Markos, S., AND B. G. BALDWIN. 2001. Higher-level relationships and major lineages of Lessingia (Compositae, Astereae) based on nuclear rDNA internal and external transcribed spacer (ITS and ETS) sequences. Systematic Botany 26: 168-183.

Mayol, M., AND J. A. Rosselló. 2001. Why nuclear ribosomal DNA spacers (ITS) tell different stories in Quercus. Molecular Phylogenetics and Evolution 19: 167-176.

McArthur, E. D., R. V. Buren, S. C. Sanderson, and K. T. Harper. 1998b. Taxonomy of Sphaeromeria, Artemisia, and Tanacetum (Compositae, Anthemideae) based on randomly amplified polymorphic DNA (RAPD). Great Basin Naturalist 58: 1-11.

McArthur, E. D., J. Mudge, R. Van Buren, W. R. Andersen, S. C. SANDERSON, AND D. G. BABbel. 1998a. Randomly amplified polymorphic DNA analysis (RAPD) of Artemisia subgenus Tridentatae species and hybrids. Great Basin Naturalist 58: 12-27.

McArthur, E. D., AND A. P. Plummer. 1978. Biogeography and management of native Western shrubs: A case study, section Tridentatae of Artemisia. Great Basin Naturalist Memoirs 2: 229-243.

McArthur, E. D., C. L. Pope, And D. C. Freeman. 1981. Chromosomal studies of subgenus Tridentatae of Artemisia: Evidence for autopolyploidy. American Journal of Botany 68: 589-605.

McArthur, E. D., And S. C. SAnderson. 1999. Cytogeography and chromosome evolution of subgenus Tridentatae of Artemisia (Asteraceae). American Journal of Botany 86: 1754-1775.

McArthur, E. D., and R. Stevens. 2004. Composite shrubs II. General technical report RMRS-GTR-136. In S. B. Monsen, R. Stevens, and N. L. Shaw [compilers], Restoring western ranges and wildlands, 493-537. U.S. Department of Agriculture, Forest Service, Rocky Mountain Research Station. Fort Collins, Colorado, USA.

McArthur, E. D., B. L. Welch, and S. C. Sanderson. 1988. Natural and artificial hybridization between big sagebrush (Artemisia tridentata) subspecies. Journal of Heredity 79: 268-276.

Mort, M. E., P. S. Soltis, D. E. Soltis, And M. L. Mabry. 2000. Comparison of three methods for estimating internal support on phylogenetic trees. Systematic Biology 49: 160-161.

Nickrent, D. L., K. P. Schuette, and E. M. Starr. 1994. A molecular phylogeny of Arceuthobium (Viscaceae) based on nuclear ribosomal DNA internal transcribed spacer sequences. American Journal of Botany 81: 1149-1160.

Nieto Feliner, G., AND J. A. Rosselló. 2007. Better the devil you know? Guidelines for insightful utilization of nrDNA ITS in species-level evolutionary studies. Molecular Phylogenetics and Evolution 44: 911-919.

Nuttall, T. 1841. Picrothamnus desertorum. Transactions of the American Philosophical Society II 7: 398-417.

Nylander, J. A. 2004. MrModeltest, v. 2. Computer program distributed by the author. Evolutionary Biology Centre, Uppsala University, Uppsala, Sweden. 
Oberprieler, C., R. Vogt, and L. E. Watson. 2007. Chapter XVI Tribe Anthemideae 342-373 In J. W. Kadereit and C. Jeffrey [eds.], Flowering plants. Eudicots. Asterales vol. VIII,. In K. Kubitzki [Series ed.] The families and genera of vascular plants. Springer-Verlag Berlin, Germany.

OHSAKo, T., AND O. OHNishi. 2000. Intra- and interspecific phylogeny of wild Fagopyrum (Polygonaceae) species based on nucleotide sequences of noncoding regions in chloroplast DNA. American Journal of Botany 87: 573-582.

Pellicer, J., S. Garcia, M. Á. Canela, T. Garnatje, A. A. Korobkov, J. D. Twibell, AND J. Vallès. 2010a. Genome size dynamics in Artemisia L. (Asteraceae): Following the track of polyploidy. Plant Biology 12: 820-830.

Pellicer, J., T. Garnatje, J. Molero, F.PustahiJa, S. Siljak-Yakovlev, AND J. VALLÈs. 2010b. Origin and evolution of the South American endemic Artemisia species (Asteraceae): Evidence from molecular phylogeny, ribosomal DNA and genome size data. Australian Journal of Botany 58: 605-616.

PosadA, D., AND T. R. BuCKLEY. 2004. Model selection and model averaging in phylogenetics: Advantages of Akaike information criterion and Bayesian approaches over likelihood ratio tests. Systematic Biology 53: 793-808

Pursh, F. T. 1814. Flora Americae septentrionalis; or, a systematic arrangement and description of the plants of North America. Richard and Arthur Taylor, Shoe-Lane, London, UK.

Qiu, Y. L., J. Lee, F. Bernasconi-Quadroni, D. E. Soltis, P. S. Soltis, M. Zanis, E. A. Zimmer, ET AL. 1999. The earliest angiosperms: Evidence from mitochondrial, plastid and nuclear genomes. Nature 402: 404-407.

RIGGINS, C. 2008. Molecular phylogenetic and biogeographic study of the genus Artemisia (Asteraceae), with an emphasis on section Absinthium. Ph.D. dissertation, University of Illinois, Urbana, Illinois, USA.

Rydberg, P. A. 1916. (Carduales), Cardueae, Tageteae, Anthemideae. North American Flora 34: 244-285.

Sanz, M., R. Vilatersana, O. Hidalgo, N. Garcia-Jacas, A. Susanna, G. M. SCHNEEWEISS, AND J. VALLÈs. 2008. Molecular phylogeny and evolution of floral characters of Artemisia and allies (Anthemideae, Asteraceae): Evidence from nrDNA ETS and ITS sequences. Taxon 57: 66-78.

Shaw, J., E. B. Lickey, J. T. Beck, S. B. Farmer, W. Liu, J. Miller, K. C. SIRIPUN, ET AL. 2005. The tortoise and the hare II: Relative utility of 21 noncoding chloroplast DNA sequences for phylogenetic analysis. American Journal of Botany 92: 142-166.

Shultz, L. M. 1983. Artemisia, sagebrush. In J. C. Hickman [ed.], The Jepson Manual, higher plants of California, 202-205. University of California Press, Berkeley, California, USA.

Shultz, L. M. 2006a. "Artemisia." In Editorial Committee [eds.], The Flora of North America and North of Mexico, vol. 21: Asterales. Oxford University Press, New York, New York, USA.

Shultz, L. M. 2006b. The genus Picrothamnus (Asteraceae: Anthemideae). In Editorial Committee [eds.], The Flora of North America and North of Mexico, vol. 19: Asterales, part 1, 498-499. Oxford University Press, New York.

Shultz, L. M. 2009. Monograph of Artemisia subgenus Tridentatae (Asteraceae-Anthemideae). Systematic Botany Monographs 89: $1-131$.

Simmons, M. P., And H. Ochoterena. 2000. Gaps as characters in sequence-based phylogenetic analyses. Systematic Biology 49: 369-381.

Soltis, D. E., P. S. Soltis, T. G. Collier, And M.L.Edgerton. 1991. The Heuchera group (Saxifragaceae): Evidence for chloroplast transfer and paraphyly. American Journal of Botany 78: 1091-1112.

Swofford, D. L. 2003. PAUP*. Phylogenetic analysis using parsimony (*and other methods), version 4. Sinauer, Sunderland, Massachusetts, USA.
Thompson, J. D., D. G. Higgins, And T. J. Gibson. 1994. CLUSTAL W: Improving the sensitivity of progressive multiple sequence alignment through sequence weighting, position-specific gap penalties and weight matrix choice. Nucleic Acids Research 22: 4673-4680.

Tkach, N. V., M. Heinrich-Hoffmann, A. A. Korobkov, and K. B. VON HAGEN K. 2008. Parallel evolutionary patterns in multiple lineages of arctic Artemisia L. Evolution. International Journal of Organic Evolution 62: 184-198.

Torrey, J., AND A. Gray. 1843. A flora of North America, vol. 2, part 3, 393-504. Wiley and Putnam. New York, New York, USA.

Torrell, M., N. Garcia-Jacas, A. Susanna, and J. Vallès. 1999. Phylogeny in Artemisia (Asteraceae, Anthemideae) inferred from nuclear ribosomal DNA (ITS) sequences. Taxon 48: 721-736.

Vallès, J., And T. GarnatJe. 2005. Artemisia and its allies: Genome organization and evolution and their biosystematic, taxonomic, and phylogenetic implications in the Artemisiinae and related subtribes (Asteraceae, Anthemideae). In A. K. Sharma and A. Sharma [eds.], Plant genome: Biodiversity and evolution, vol. 1, part B: Phanerogams, 255-285. Science Publishers, Enfield, New Hampshire, USA.

VallÈs, J., AND E. D. MCArThur. 2001. Artemisia systematics and phylogeny: Cytogenetic and molecular insights. In E. D. McArthur, D. J. Fairbanks [compilers], Shrubland ecosystem genetics and biodiversity: Proceedings, 67-74. Department of Agriculture, Forest Service, Rocky Mountain Research Station, Provo, Utah, USA.

Vallès, J., M. Torrell, T. Garnatje, N. Garcia-Jacas, R. Vilatersana, AND A. Susanna. 2003. The genus Artemisia and its allies: Phylogeny of the subtribe Artemisiinae (Asteraceae, Anthemideae) based on nucleotide sequences of nuclear ribosomal DNA internal transcribed spacers (ITS). Plant Biology 5: 274-284.

VAn Der Meersch, H. 2005. Review of the use of artemisinin and its derivatives in the treatment of malaria. Journal de Pharmacie de Belgique 60: 23-29.

WARD, G. H. 1953. Artemisia section Seriphidium in North America: A cytotaxonomic study. Contributions from the Dudley Herbarium. Stanford University. 4: 155-205.

Watson, L. E., P. L. Bates, T. M. Evans, M. M. Unwin, and J. R. Estes. 2002. Molecular phylogeny of subtribe Artemisiinae (Asteraceae), including Artemisia and its allied and segregate genera. BMC Evolutionary Biology 2: 17.

Weber, W. A. 1984. New names in Artemisia. Phytologia 55: 7-9.

WEST, N. E. 1983. Western Intermountain sagebrush-steppe. In N. E. West [ed.], Ecosystems of the world, 5: Temperate deserts and semideserts, 351-374. Elsevier Scientific Publishing, Sussex, UK.

White,T.J.,T.D.Bruns, S.B.LeE, AndJ.W.TaYlor.1990. Amplification and direct sequencing of fungal ribosomal RNA genes for phylogenetics. In M. A. Innis, D. H. Gelfand, J. J. Sninsky, and T. J. White [eds.], PCR protocols: A guide to methods and applications, 315-322. Academic Press, San Diego, California, USA.

Whitten, W. M., N. H. Williams, and M. W. Chase. 2000. Subtribal and generic relationships of Maxillarieae (Orchidaceae) with emphasis on Stanhopeinae: Combined molecular evidence. American Journal of Botany 87: 1842-1856.

Winkworth, R. C., D. Bryant, P. J. Lockhart, D. Havell, and V. Moulton. 2005. Biogeographic interpretation of splits graphs: Least squares optimization of branch lengths. Systematic Biology 54: 56-65.

WINWARD, A. H. 1970. Taxonomic and ecological relationships of the big sagebrush complex in Idaho. Ph.D. dissertation, University of Idaho, Moscow, Idaho, USA.

Winward, A. H., AND E. D. McArthur. 1995. Lahontan sagebrush (Artemisia arbuscula ssp. longicaulis): A new taxon. Great Basin Naturalist 55: 151-157.

YANG, Z., AND B. RANNALA. 1997. Bayesian phylogenetic inference using DNA sequences: a Markov chain Monte Carlo method. Molecular Biology and Evolution 14: 717-724. 